\title{
COASTAL GEOMORPHOLOGY, McMURDO SOUND, ANTARCTICA
}

\author{
By Robert L. Nichols \\ (Department of Geology, Tufts University, Medford, Massachusetts 02 I55, U.S.A.)
}

Anstract. Well-developed elevated beaches, deltaic deposits, marine-boulder pavements and wavewashed bedrock surfaces are found from Cape Bernacchi north to Granite Harbour. The highest measured marine feature, an elevated beach at Dumlop Island, is $20 \mathrm{~m}(67 \mathrm{fi})$ above sea-level. The highest beaches at Marble Point and Cape Roberts, about $48 \mathrm{~km}$ (30 miles) apart, are about $20 \mathrm{~m}$ ( $66 \mathrm{ft}$ ) above sea-level. The marine limit between these two points is, therefore, essentially horizontal. The highest beach at Cape Bernacchi. approximately $4.8 \mathrm{~km}$ (3 miles) south of Marble Point. is about $12 \mathrm{~m} \mathrm{(4o} \mathrm{ft)} \mathrm{above} \mathrm{sea-level.}$ Well-developed elevated beaches disappear about $3.2 \mathrm{~km}$ (2 miles) south of Cape Bernacchi and are not found between this point and Koctlitz Glacier.

These beaches post-date the youngest glaciation recognized in the lower Wright Valley, $\mathrm{A} " \mathrm{C}$ analysis of an elephant seal buried in a $13 \mathrm{~m}\left(44 \mathrm{ft}\right.$ ) beach at Marble Point indicates that this beach is $445^{\circ} 150$ years old. As sea-level at this time was approximately $3 \mathrm{~m}$ (ro ft) lower than at present, the Marble Point area has risen isostatically about $16 \mathrm{~m}(54 \mathrm{ft})$ during the last $4450+150$ years.

Pitted beaches, beaches deposited on ice, a buried elephant seal and gravel ridges deposited by ice indicate that all of the beaches were formed in a climate like that now found in the area.

RÉsumé. Géomorphologie côtière, McMurdo Sound, Antarctiqué. An nord du Cape Bernacchi jusqu'à Granite Harbour, on trouve des plages élevées bien développées, des deltas alluvionnaires, des pavages de galets marins et des bancs de rocher lavés par les vagues. L'élément d'origine marine le plus haut qui ait été mesuré, une plage élevée à Dunlop Island, est à $20 \mathrm{~m}$ au-dessus du niveau de la mer. Les plages les plus hautes à Marble Point et Cape Roberts séparées par une distance d'environ $48 \mathrm{~km}$, sont à une altitude de quelque $20 \mathrm{~m}$. Ainsi la limite marine entre ces deux points est essentiellement horizontale. La plus haute plage au Cape Bernacchi, approximativement $4.8 \mathrm{~km}$ au sud de Marble Point. est environ $12 \mathrm{~m}$ au-dessus du niveau de la mer. Des plages élevées bien développées disparaissent environ $3.2 \mathrm{~km}$ au sud du Cape Bernacchi; il n'y en a pas entre ce point et Koettlitz Glacier.

Ces plages sont postérieures à la dernière glaciation reconnue dans la partie inférieure de la Wright Valley. L'analyse au ${ }^{4} \mathrm{C}$ d'un éléphant de mer enfoui dans une plage de $13 \mathrm{~m}$ d'altitude à Marble Point indique pour celle-ci un áge de $4450=150$ ans. Comme à cette époque le niveau de la mer était approximativement $3 \mathrm{~m}$ plus bas que maintenant. les environs de Marble Point sont montés isostatiquement
d'environ $16 \mathrm{~m}$ pendant cette période.

Des plages montrant des creux. des plages formées sur la glace, un éléphant de mer enfoui et des crétes de gravier déposées par la glace indiquent que l'ensemble des plages a été formé sous un climat identique à celui qui règne actucllement dans cette région.

Zusammenfassung. Kïstengeomorphologie am Mc.Murdo Sound, Antarktika. Von Cape Bernacchi nordwärts bis Granite Harbour wurden gutausgebildete Strandterrassen, Deltaablagerungen, marine Steinstrande und von der Brandung bearbeitete Felsfächen gefunden. Die höchste vom Mcer gebildete Form ist eine Strandterrasse auf Dunlop Island, $20 \mathrm{~m}(67 \mathrm{ft})$ über dem Mecresspiegel. Bei Marble Point und Cape Roberts. also etwa $48 \mathrm{~km}$ (30 Meilen) entfernt, liegen die höchsten Strandterrassen ebenfalls etwa $20 \mathrm{~m}$ (66 ft) über dem Meeresniveau. Die oberste Strandlinic ist demnach zwischen diesen beiden Punkten im wesentlichen horizontal. Die höchste Strandterrasse am Cape Bernacchi, etwa $4.8 \mathrm{~km}$ (3 Meilen) südlich von Marble Point, liegt etwa $12 \mathrm{~m}$ (40 ft) über dem Meeresniveau. Etwa $3.2 \mathrm{~km}$ (2 Meilen) südlich von Cape Bernacchi verschwinden die gut ausgebildeten Strandterrassen und treten bis zum Koettlitz Glacier nicht mehr aul.

Diese Terrassen lassen eine Datierung der jüngsten im unteren Wright Valley festgestellten Vergletscherung zu. Die ${ }^{4} \mathrm{C}$-Analyse eines See-Elefanten, der in ciner $13 \mathrm{~m}(44 \mathrm{fi})$ hohen Strandterrasse bei Marble Point lag, ergab für diese Terrasse cin Alter von $445^{\circ}+150$ Jahren. Da zu jener Zeit der Meeresspiegel etwa $3 \mathrm{~m}$ ( $10 \mathrm{ft}$ ) tiefer war als heute, hat sich das Gebiet um Marble Point während der letzten $445^{\circ}+15^{\circ}$ Jahre um $16 \mathrm{~m}(54 \mathrm{ft})$ isostatisch gehoben.

Strände mit Toteislöchern, Strandterrassen auf Eis, ein verschütteter See-Elefant und vom Eis abgelagerte Schuttwälle deuten darauf hin, dass alle diese Strandformen in einem Klima entstanden, das dem heutigen Klima des Gebietes glich.

\section{INTRODUCTION}

The area considered in this paper is in east Antarctica, along the coast of south Victoria Land, on the west side of McMurdo Sound, between lat. $77^{\circ} \mathrm{oo}^{\prime}$ and $78^{\circ} \mathrm{oo}^{\prime} \mathrm{S}$., and long. $162^{\circ}$ and $165^{\circ} \mathrm{E}$. It extends from Granite Harbour in the north to Cape Chocolate in the south (Fig. 1). The geomorphic features described are those found between the marine limit and the present shoreline. 
The field work was carried out between 1957 and 1961. In 1957-58 the writer was employed by Metcalf and Eddy, Engineers, Boston, Massachusetts, who were under contract with the U.S. Navy to make engineering studies in this area. The $195^{8-59}$ field season was financed by the Arctic Institute of North America under International Geophysical Year auspices, and the $1959^{-60}$ and $1960-61$ field seasons by the National Science Foundation.

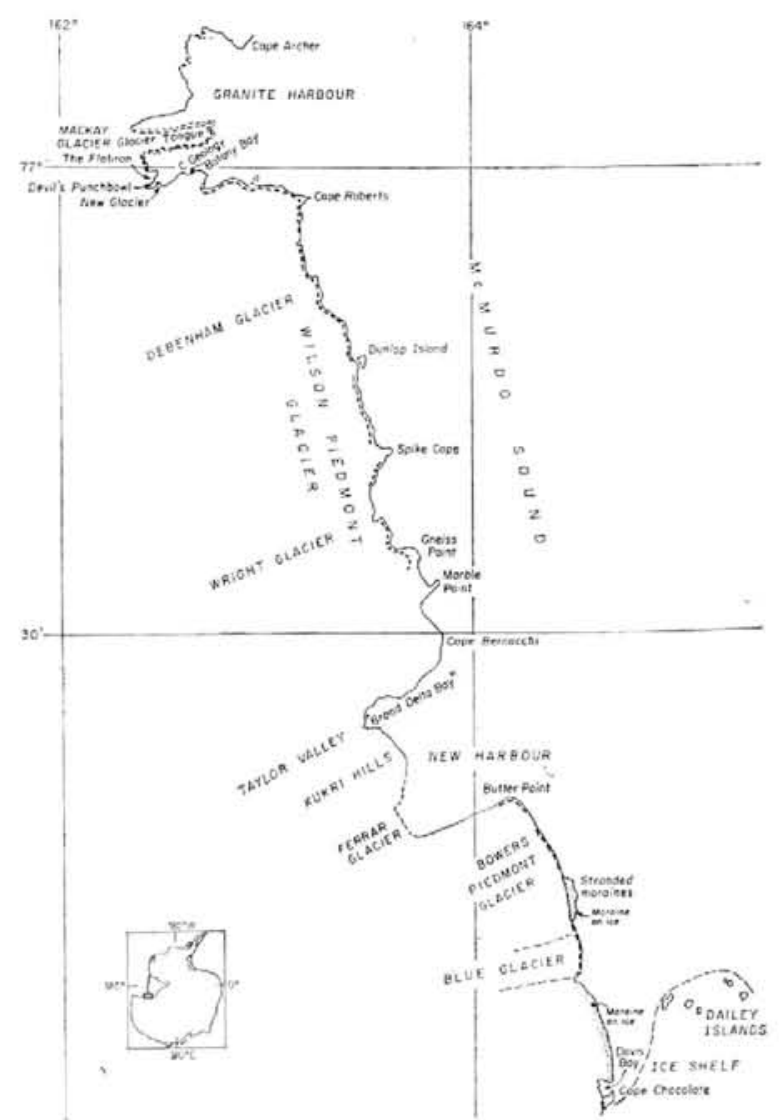

Fig, 1, Map showing the localities in the McMurdo Sound area which were studied.

\section{Kinds of Coasts Found along McMurdo Sound}

The following types of coasts are found between Cape Chocolate and Granite Harbour Nichols, 1963[a]) (Fig. 1): (I) Bedrock coasts (18 km, II miles). Found at Gneiss and Marble Points, Spike Cape, Cape Bernacchi and elsewhere. (2) Ice-cliff coasts $\left(77 \mathrm{~km}, 4^{8}\right.$ miles). The ice cliffs have been cut in piedmont glaciers (Bowers and Wilson Piedmont Glaciers), channel glaciers (Lower Wright Glacier), outlet glaciers (McKay, Ferrar and Koettlitz Glaciers), alpine glaciers (Blue Glacier), snowdrift-ice slabs (Gneiss Point) and the ice foot (Gneiss Point and between Blue Glacier and Davis Bay). (3) Ice-cored moraine coasts (1 4 km, 9 miles). Found at Cape Chocolate, Stranded Moraines and from the north side of Davis Bay to the south side of Blue Glacier. (4) Mantle-rock coasts (48 km, 30 miles). This type can be subdivided into the following: (a) alluvial coasts consisting of alluvial aprons and fan deltas (Davis Bay, "Broad Delta Bay", between Ferrar Glacier and "Broad Delta Bay", and elsewhere); (b) morainal ("Broad Delta Bay") (Shepard, 1937, p. 6o7); (c) elevated 
beach coastal plains (the beaches may or may not rest on ice (Nichols, 1961[a], [b])) (Table I); (d) talus (Granite Harbour).

\section{SNOWdrifT-1Ce Slabs}

Several more or less permanent patches of ice, most of which are not continuous with Wilson Piedmont Glacier, are found in the Gneiss Point area. 'Their proximity to the glacier at first suggests that they are detached stagnant remnants of the glacier. They are, however. snowdrift-ice slabs (Wright and Pricstley, 1922, p. ${ }_{15} \mathrm{I}_{-52}$; Nichols, [1953], p. $102-05,1960$, p. $1444-45,1964$ ).

The prevailing winter wind is from the south, as proved by the following evidence: ( 1 ) ventifacts are cut and polished only on their south sides; (2) the sand shadows which form in the lee of obstacles occur on the north sides; (3) most of the grains and flakes blown from blocks of marble and other rapidly weathering rocks are on the north sides of the blocks; (4) the largest snowdrifts are on the north sides of obstacles; and (5) the lee bedding in the snow barchans on the sea ice invariably slopes northward.

All the ice slabs that were studied are on north-facing slopes. This is what would be expected if they were snowdrift-ice slabs, for although insolation is greater on north-facing slopes, snow would be deposited in greatest amount there because the prevailing winds are from the south. The writer visited several of these ice slabs during the spring before an appreciable amount of snow had ablated, and observed that the snow was deeper on north-facing slopes than elsewhere. Dirt layers in the ice slabs that were studied parallel the sloping surfaces of the ice slabs. This also suggests that they are snowdrift-ice slabs and not remnants of the glacier.

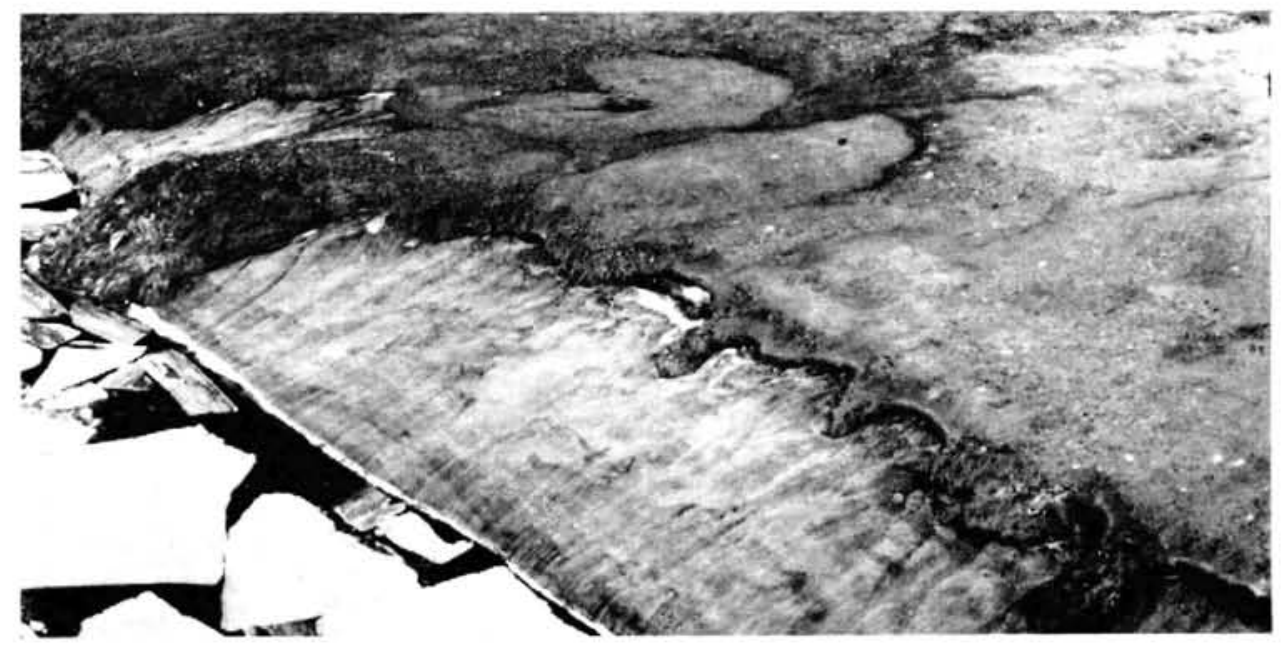

Fig. 2. A large and a small snowdrifl-ice slab between Wright Glacier and Gneiss Point. The scalloped inner margin of the large stab may be due to nivation. Only a small patch of the previons winter's snowe remains. The marine limit is a short distance above the inner margins of the slabs (U.S. Nazy pholograph).

The snowdrift-ice slabs between Wright Glacier and Gneiss Point (Fig. 1) extend for approximately $1.6 \mathrm{~km}$ ( $\mathrm{r}$ mile) along the coast. They slope northward and extend from an upland surface down to sea-level. They are below the marine limit and formed, therefore, after the highest stand of the sea (Fig. 2). As the sea dropped in relation to the land, the snowdrift-ice slabs increased in size, growing outward and downward. They are undoubtedly less than $18 \mathrm{~m}(60 \mathrm{ft})$ thick. The absence of crevasses and the fact that their surfaces slope only I $5^{\circ}$ prove that they do not move. Talus, and fluvial and beach deposits veneer them in places. 


\section{Elevated Wave-washed Surfaces}

Elevated wave-washed bedrock surfaces, present at Marble Point, Cape Roberts, Spike Cape, Cape Bernacchi and elsewhere, are best developed at Gneiss Point (Fig. I). Here the wave-washed surface, which extends from the marine limit down to the present sea-level and for $900 \mathrm{~m}(3000 \mathrm{ft}$ ) along the coast, contrasts sharply with the area above it (Figs. 3 and 4 ). An indistinct elevated beach is commonly found immediately above the wave-washed surface. Bedrock surfaces, till, and kame and solifluction deposits are found still higher up. An occasional elevated pocket beach and thin eolian deposits, and residual sand and gravel formed

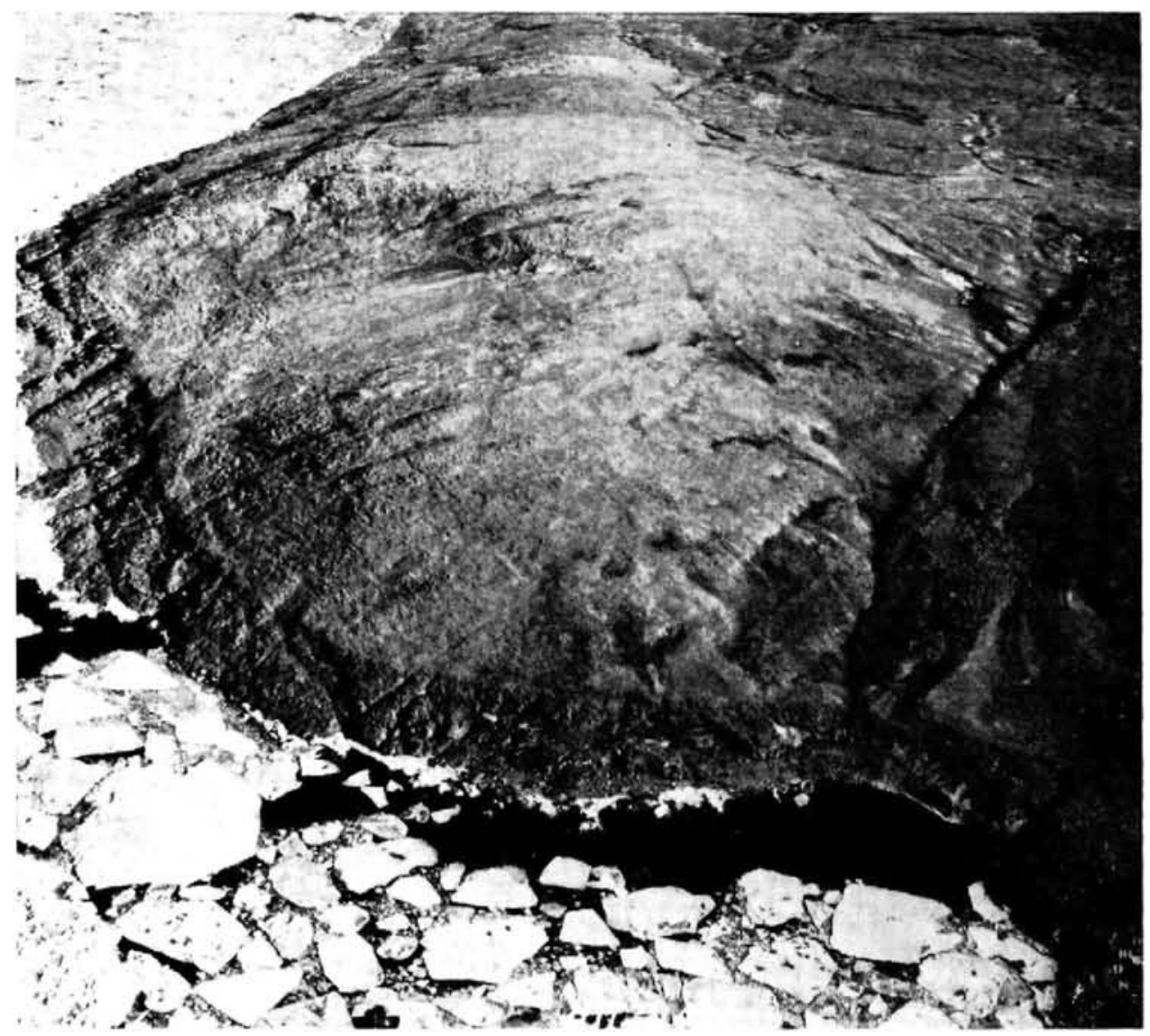

F.g. 3. Elevaled wave-washed surfaces and glacial grooves in bedrock al Gneiss Point (U.S. Navy photograph).

by the weathering of the bedrock after the formation of the wave-washed surface, are found in the wave-washed area. Small solifluction lobes and sheets cover some of the uppermost part of the area. Also present is fluvial material deposited by streamlets formed by the melting of snowdrifts. The fluvial material occurs in thin layers and in fans $1.0-1.5 \mathrm{~m}(3-4 \mathrm{ft})$ long and many centimeters (several inches) thick. Small amounts of silt and sand of eolian and fluvial origin are commonly found interbedded in and veneering snowdrifts. Snowdrift morainal deposits form when the snow melts and this material is let down. These deposits with their micro-morainal topography are easily identified and are common in the wave-washed area. In general, only fine-grained mantle rock is found in the wave-washed area, whereas both fine 
and coarse mantle rock are found above it. Figures 3 and 4 show chasms with diverse orientation. Most, if not all, of the chasms have been formed by glacial erosion along zones of weakness. The upper limit of the wave-washed surface is probably between 18 and $21 \mathrm{~m}$ (6o and $70 \mathrm{ft}$ ) above sea-level.

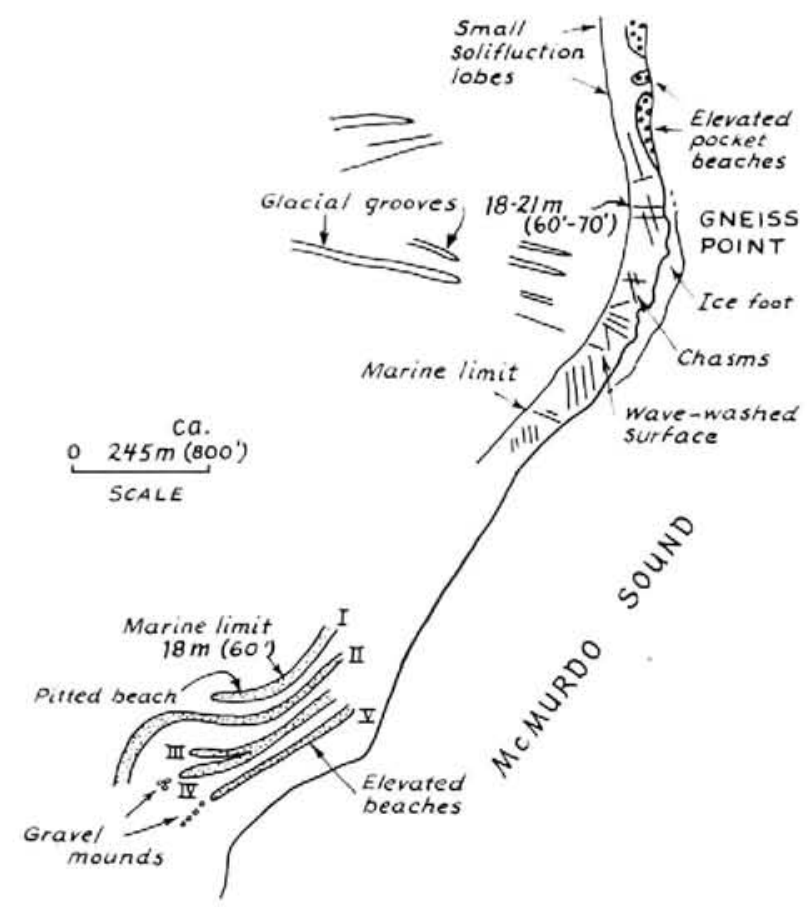

Fig. 4. Map showing the wave-washed surfaces at Gneiss Point and the elevated beaches just south of it.

\section{Elevated Marine-boulder Pavements}

An elevated marine-boulder pavement on a small promontory between Wright Glacier and Gneiss Point (Figs. I and 5) is flanked on two sides by snowdrift-ice slabs; inland it terminates against till and thin kame-hillock deposits; on the seaward side it is bordered by bedrock which extends downward to sea-level. It is found on a flattish area about $100 \mathrm{~m}$ $(328 \mathrm{ft})$ long and somewhat less in width very close to the marine limit. The boulders have been slightly rounded and cover more than three times as much area as does the matrix. This pavement was undoubtedly derived from a bouldery till. Elevated beach gravels close by are at about the same elevation. The pavement was in a very exposed position when it was being acted upon by waves, as the snowdrift-ice slabs which flank it today did not then exist.

This boulder pavement can be differentiated from bouldery till and from felsenmeers only with difficulty. The slight rounding of the boulders, the great concentration of boulders, its exposed position with respect to the ocean, its gentle seaward slope, its relationship to the marine limit and the presence of nearby elevated beach deposits at about the same elevation prove its marine origin.

Another marine-boulder pavement associated with elevated beach gravels is at a slightly lower elevation on the peninsula immediately east of this pavement. 


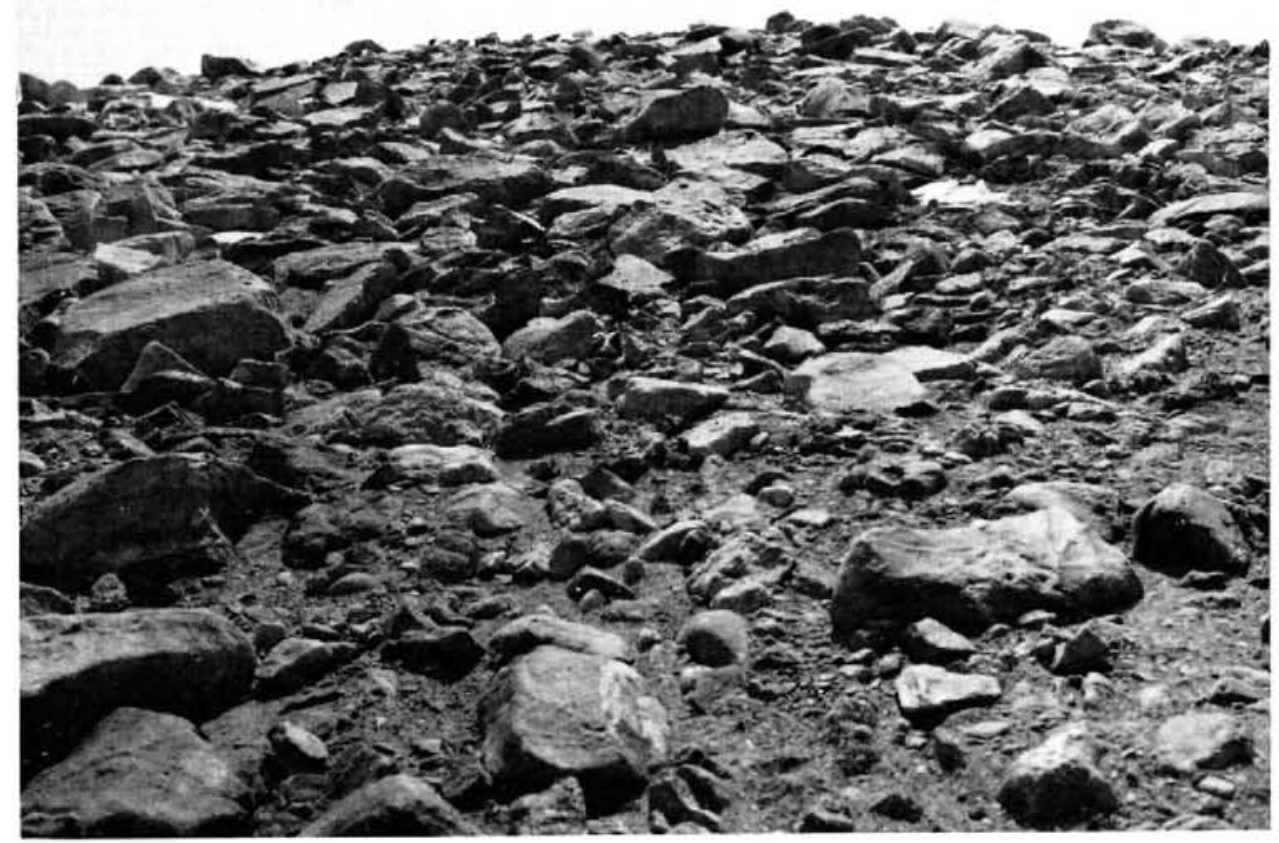

Fig. 5. An elevated marine-boulder pavement between Gneiss Point and Wright Glacier.

\section{Previous Work on Elevated Beaches}

Priestley (1922, p. 442-44; 1923, p. 53-59) and Taylor (I922, p. 22-23) have described elevated beaches along the coast of south Victoria Land. Priestley found an elevated beach $24 \mathrm{~m}$ (80 ft) above sea-level at Terra Nova Bay. This is the highest beach Priestley described and it is higher than any this writer has seen. Priestley also noted the beach ridges at Cape Bernacchi and Dunlop Island. Taylor described an elevated beach in Granite Harbour near Cape Geology which is approximately $15 \mathrm{~m}(5 \circ \mathrm{ft})$ above sea-level. Priestley believed that the elevated beaches prove a recent uplift has taken place all along the coast of south Victoria Land, and he correlated this uplift with crustal re-adjustments resulting from deglaciation.

In addition to the elevated beaches, sponge spicules, sponges, diatoms, Foraminifera, molluscan shells, echinoid spines, Serpulae, Polyzoa and ocean-bottom deposits have been found on Ross Island $49 \mathrm{~m}$ ( $160 \mathrm{ft}$ ) above sea-level and at lower elevations elsewhere (David and Priestley, 1909, p. 275-77, 306-07, 1914, p. 266-76; Priestley and David, 1912, p. 808-10; Debenham, I 920 , p. $5 \mathrm{I}-59$ ). These organisms are now found in water of some depth, and David and Priestley first thought they indicated a crustal uplift of between 60 and $90 \mathrm{~m}$ (200 and $300 \mathrm{ft}$ ). However, later they discarded the idea that the deposits were raised beaches or marine deposits and suggested that (I) the deposits might have been pushed upward from the bottom of the ocean by glacial ice, or (2) they might have been deposited on submerged glacial ice which had sunk on reaching the ocean because of the weight of the morainal material and which, when relieved of some of its morainal load, floated upward (David and Priestley, r9r4, p. 270-7I). Debenham (I920, p. 6I-7I) suggested that the material froze to the bottom of a grounded glacier and that ablation then removed ice from the surface of the glacier. As it was 
now thinner, it detached itself from the ocean bottom and, with the organisms and marine deposits still adhering to it, floated upward. Following this, the water beneath the glacier froze to the bottom of the glacier immediately beneath the adhering organisms and oceanbottom deposits. By a continuation of ablation at the surface of the glacier and freezing of salt water at the bottom of the glacier, the material slowly moved upward.

The data obtained by the writer on the altitude of the marine limit from Granite Harbour south to Cape Chocolate are in substantial agreement with the observations made by Priestley $(1922,1923)$ and Taylor (1922). They are not in agreement with the much greater uplift originally suggested by David and Priestley (1914).

\section{General Description of Elevated Beaches}

The maximum altitudes of the elevated beaches studied by the writer are listed in Table I.

The following criteria were used to determine the marine limit: (I) ridge-and-swale topography commonly characterizes the elevated beaches, but is not found on the mantle-rock deposits above them; (2) the area above the marine limit commonly contains large boulders, whereas the beach deposits are composed of finer-grained material; (3) silt is present in the glacial deposits above the marine limit but it is not common in the better-sorted marine deposits below the marine limit; (4) in general, more angular material is found above the marine limit and more rounded material below the marine limit; $(5)$ kenyte is not found above the marine limit and, except in one locality, neither is basaltic scoria; they are common below the marine limit, however, having been rafted to the area by icebergs and sea ice; $(6)$ many of the highest elevated beaches are pitted, whereas the material above the marine limit, with the exception of some outwash, is not pitted.

Beaches formed in polar climates are characterized by features that generally are not found on beaches formed in non-polar climates (Nichols, I96 I[a], [b]). Of these features some of the beaches along McMurdo Sound have the following: (1) They rest on ice (Fig. 6). (2) They are pitted (Fig. 7). (3) They have ridges and mounds formed because of ice push and/or deposition from stranded ice. (4) They have beach ridges that terminate abruptly because glacial ice was present when they were formed. (5) Ice-rafted fragments are found on them. (6) They have poorly rounded beach stones. (7) Frost cracks and mounds, stone circles and polygons, and solifluction deposits are found on them. (8) The beach ridges may have short erosional gaps that were formed by melt-water streams. (9) Ventifacts are present. (I0) They contain cold-water fossils.

Solifluction sheets, till, outwash, talus, eolian deposits and bedrock are found above the marine limit. Till, outwash, talus and perhaps solifluction deposits have been sources for the beach deposits, and the re-working of higher beaches by streams has furnished material for some of the lower beaches. Kenyte and scoria, in general, are not indigenous to the area. Their presence on the beaches proves that material transported by icebergs and sea ice is also a source for the beach deposits. Elevated ocean-side, bay-side, pocket and bay-mouth beaches are present, together with elevated tombolos and spits. As might be expected, the lower beaches are composed of gray gravel, whereas the higher older beaches are composed of somewhat weathered yellow or light brown gravel. Owing to the rapidity of uplift, to the fact that the sea is open only for a few months every year, to the presence of an ice veneer on some of the beach stones for part of the time when there is open water and to the presence of an ice foot and/or stranded pieces of ice on the beaches when there is open water, the beach gravels are not well rounded by wave action. Exfoliation has rounded some of the beach stones but only on the upper side. This creates the false impression that wave action was an effective rounding agent.

The beaches are veneered in places by solifluction, fluvial and eolian deposits. Excellently developed ridge-and-swale topography is common. Small elongated ponds are found in some 
Tart.f. 1. Elevated Benches of McMlrdo Sound, Souti Victoria Land, Antarctica

Location

$\begin{array}{cc}\text { Maximum } \\ \text { altitnde } \\ \text { n } & \text { ft } \\ \text { 14 } & (47) \\ \text { I7 } & (56) \\ 9 & (30) \\ 19 & (63) \\ 17 & (56) \\ 14 & (47) \\ 20 & (66)\end{array}$

Dumlop Island

Spike Cape and adjacent mainland

Imudediately north of Wright Glacier

Inmediately west of mouth of "Scheuren River"

Immediately east of mouth of "Scheuren River"

Immediately north of Gineiss Poiru

Inmediately south of Gneiss Point

Immediately north of "Surko River"

Immediately south of "Surko River"

Marble Puint near pitted bcach

Eastern tip of Marble Point

Immediately north of "South River"

Inmediately south of "South River"

Cape Bernacchi

[.6 km (1 mile) south of Cape Bernacchi

$3 \mathrm{~km}$ (2 miles) south ol Cape Betnacchi

South-east of "Broad Delta Bay"

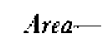

dimensions

Special fealures

Remarks

Small

Poorly developed

Individual marine roundstones found $3 \mathrm{~m}$ ( $10 \mathrm{ft}$ ) higher

Undoubtedly goes higher; snow prevonted measurement

Well-dovcloped wavewashed bedrock surface

Described by "laylor (1922)

Tied islands and elevated tombolos
20 (67) a.6 kul (1 mile) long: $0.8 \mathrm{~km}$ ( 0.5 mile) wide

$17(55)$

$77 \quad(56)$

$20 \quad(64)$

$20 \quad(64)$

$20 \quad 65)$

$18 \quad(60)$

I9 (61)

$17\left(5^{6}\right)$

$20 \quad(66)$

$20 \quad(65)$

$14 \quad(46)$

$12 \quad(41)$

I $2(40)$

$5(17)$

$3 \quad(9)$

$3(\mathrm{co})$
Excellently developed beach ridges

Well-developed beach ridges terminating against glacier and nearly perpendicular to it
Elevatod beach ridges terminating against glacier and perpendicular $t o$ it ; elevated wave-washed bedrock and marine boulder pavements

Elevalted wave-washed bedrock also present

Elevated wave-washod bedrock: highest beach pitted in places; glacial deposits ibove beaches badly weathered

Highest beach pitted

U.S. Navy Survey

L.S. Navy Survey

U.S. Navy Survey

L.S. Navy Survey

U.S. Navy Survoy

Pile of boulders surrounded by solifuction deposits; probably an elevared beach

Marine limit may be higher

Boutder beach

Rounded boulders 


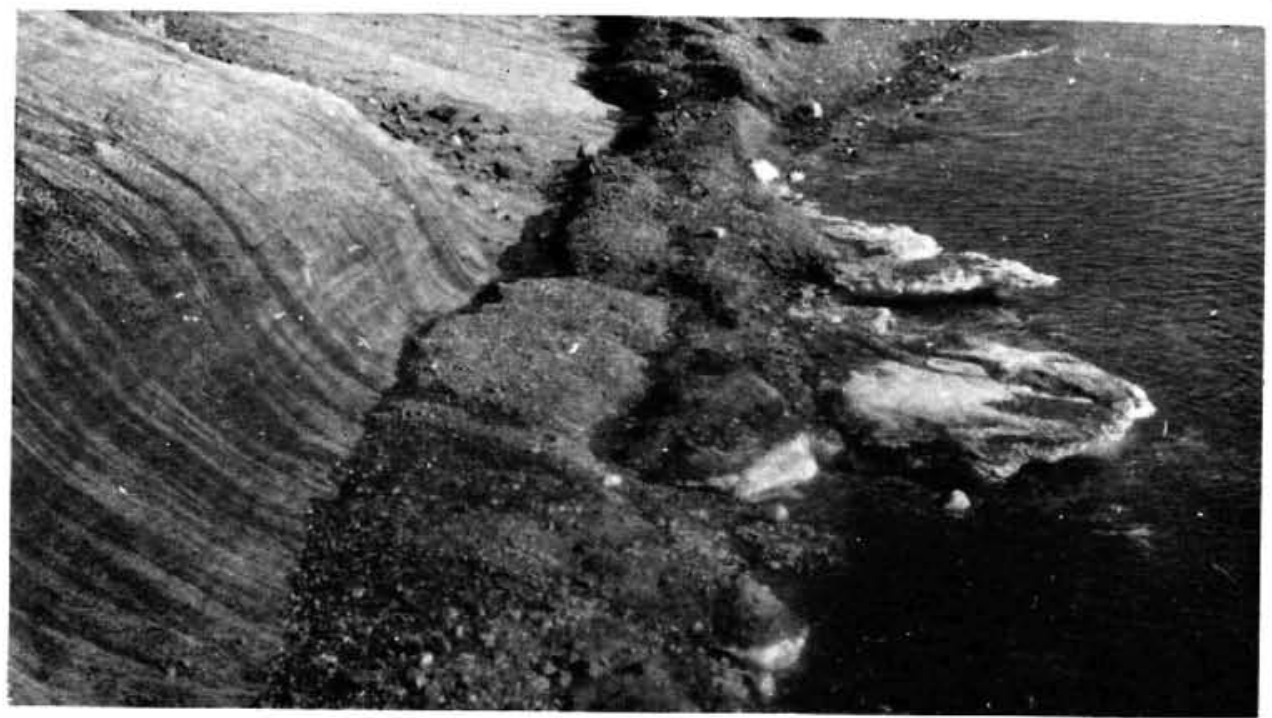

Fig. 6. A beach, between Wright Glacier and Gineiss Point, which rests on ice. Snowdrift-ice slabs at the left and an ice foot, on which the beach was deposited, at the right.

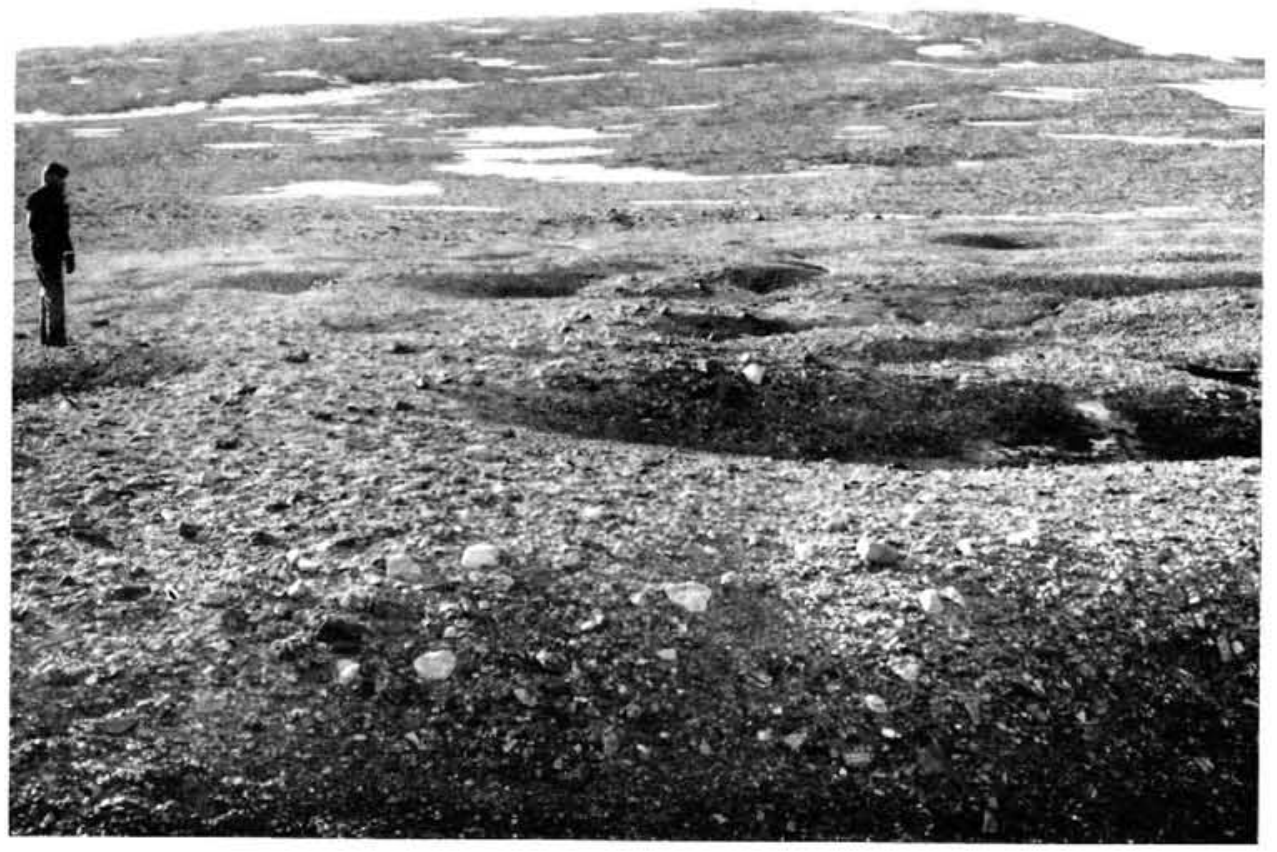

Fig. 7. A pilled elecated beach at Marble Point approximalely $15 \mathrm{ft}(1.3 .7 \mathrm{~m})$ above sea-level. The pits are in general $10-50 \mathrm{ft}$ $(3.0-15.2 \mathrm{~m})$ in diameter and as much as $6 \mathrm{ft}(1.8 \mathrm{~m})$ deep. 
of the swales. Deposits $0.6 \mathrm{~m}(2 \mathrm{ft})$ or more thick, composed of material notably finer than the gravel of which the beach ridges are formed, are common in the swales. These deposits are eolian, fluvial, lacustrine and marine in origin. Boulders many feet long surrounded by beach gravel are found in places below the marine limit. They were either deposited by the glacier as part of the till sheet beneath the beach deposits or ice-rafted and deposited in relatively deep water after the glacier retreated but before the beach ridges were completely formed. They also indicate that the beach deposits are not thick.

During the full-bodied stage of glaciation, Wilson Piedmont Glacier and others terminated in deep water. It seems likely that the oldest beaches were formed close to where the glaciers, during their retreat, first uncovered land. With continued retreat and crustal uplift consequent on deglaciation, younger and lower beaches were formed. The first beaches were formed at the termini of the glaciers, and younger and younger beaches were formed at increasing distances from them. Several features indicate that the first beaches were formed close to the glaciers. The highest beaches in many places are pitted. Pits are not found in general on the lower beaches. This suggests that the pits were formed by the melting of fragments of ice which fell from the glaciers onto the beaches and were buried by beach gravels. A gap approximately $30 \mathrm{~m}$ ( $\mathrm{r} 00 \mathrm{ft}$ ) long is found in the highest beach ridge near Marble Point. It seems likely that this gap resulted from the erosional activity of a melt-water stream which came from Wilson Piedmont Glacier when it was close to the beach. The highest beach in the southern part of the mainland near Spike Cape is abruptly truncated on the south. The presence of Wilson Piedmont Glacier in the area where the highest beach is not now found, when this beach was being formed elsewhere followed by glacial retreat, is responsible for the truncation. The absence of the highest beach ridge of the Marble Point area on a kame ridge near the mouth of the "Surko River" indicates the presence of a glacier on the kame when the highest beach was being formed elsewhere (Fig. 8).

\section{Elevated Beaches in Granite Harbour}

Elevated beaches are found at several places in Granite Harbour (Fig. I). An elevated beach approximately $19 \mathrm{~m}\left(6_{3} \mathrm{ft}\right)$ above sea-level (hand-level survey) is found in a chasm at Cape Geology (Fig. I), close to the stone hut built by members of Scott's western geological party. Extensive elevated wave-washed bedrock surfaces are also found here. A continuous elevated beach extends for some distance south-west of Cape Geology. It is $17 \mathrm{~m}$ ( $56 \mathrm{ft}$ ) above sea-level (hand-level survey) at one point. Toward New Glacier the beach disappears, perhaps because the topography near the strand line may be too steep for the formation of beaches. A continuous elevated beach approximately $46 \mathrm{~m}(\mathrm{I} 5 \mathrm{oft}$ ) wide and about $0.8 \mathrm{~km}$ $\left(0.5\right.$ mile) long along Botany Bay (Fig. I) is at least $17 \mathrm{~m}\left(5^{6} \mathrm{ft}\right.$ ) above sea-level (hand-level survey) at one point, and scattered beach stones are as much as $20 \mathrm{~m}(66 \mathrm{ft})$ above sea-level. It is a well-rounded boulder beach and the upper part, in places, is buried by talus and solifluction deposits. The glacial material immediately above the beach is stained yellow, whereas the beach deposits are gray. This color-contrast contact between the two deposits appears sharp when seen from a short distance. It is not known whether this difference is due to a higher percentage of fine-grained material in the glacial deposits which causes them to weather more rapidly and to better retain the limonite produced by the weathering, or whether less snow collects on the steeper terrain where the glacial deposits are found, allowing more weathering to take place, or whether differences in the age or lithology of the two deposits are responsible. A poorly developed bouldery elevated beach at the foot of The Flatiron less than $1.6 \mathrm{~km}$ ( $\mathrm{I}$ mile) north-east of Devil's Punchbowl (Fig. I), in places, is $14 \mathrm{~m}(47 \mathrm{ft}$ ) above sea-level (hand-level survey) and perhaps still higher parts have been buried by talus and landslide deposits. 
An elevated boulder beach more than $300 \mathrm{~m}$ ( $\mathrm{t}$ ooo ft) long on the south side of Devil's Punchbowl (Fig. I) terminates on the east close to New Glacier; on the west, near the head of Devil's Punchbowl, a talus slope replaces the beach. One part of the beach is $9 \mathrm{~m}$ (3o ft) above sea-level (hand-level survey) but the marine limit could not be determined because of the snow cover. The beach is veneered in some places with eolian sand and in others by an alluvial fan. It is more weathered than any elevated beach seen by the writer along McMurdo Sound. The boulders have been rounded by exfoliation and between them is a veneer of exfoliated grains and fragments. Neither the location nor the altitude of this beach suggests that it is older than the other beaches in the area. It seems likely that the considerable degree of weathering is due to the fact that the red granite of which many of the boulders are composed weathers rapidly.

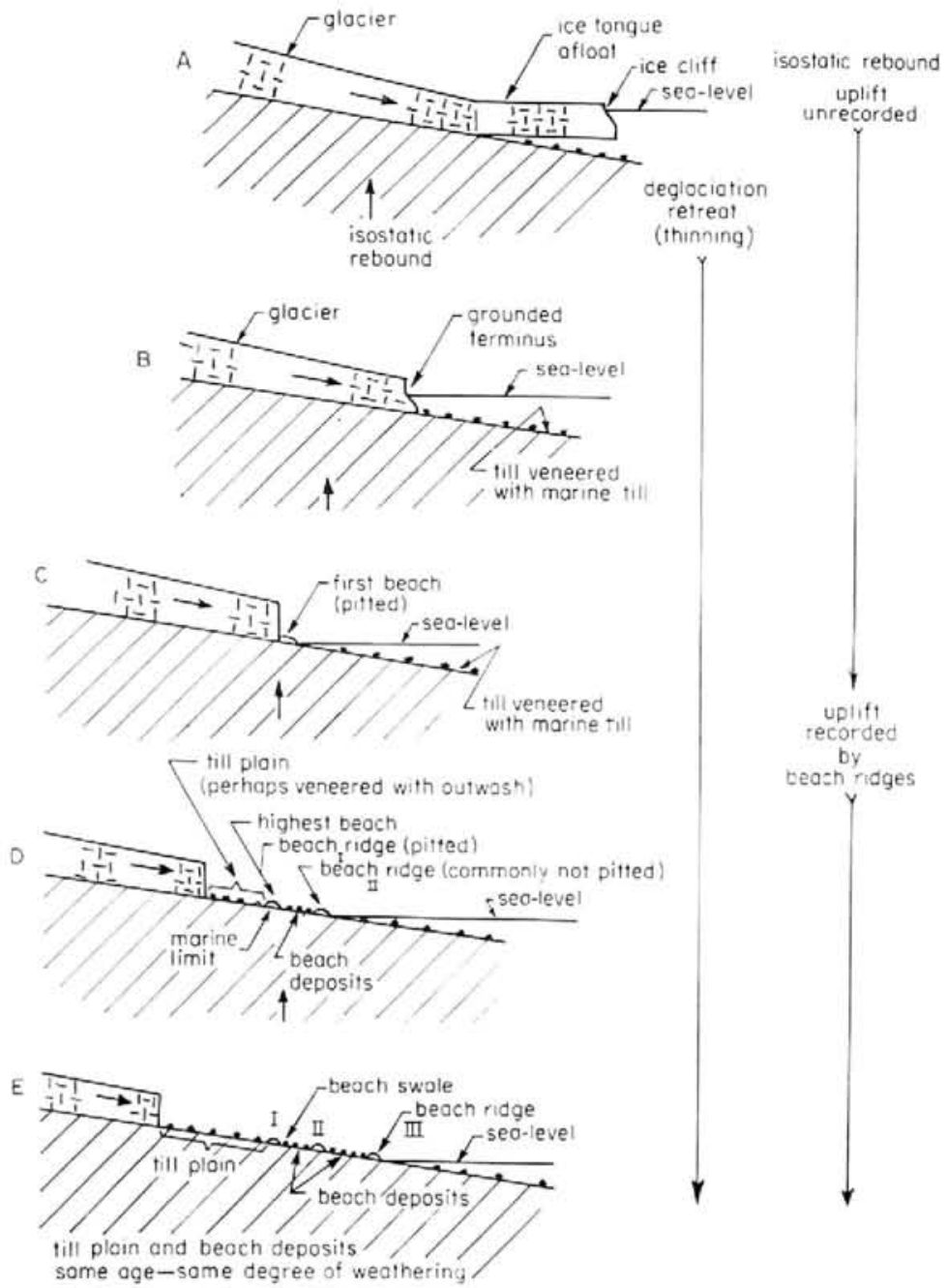

Fig. 8. Diagrams showing the development of elevated beaches because of isostatic rebound, and the formation of pits on the highest beach because the terminus of the glacier is immediately aljacent to the beach. 


\section{Elevated Beaches at Cape Roberts}

Cape Roberts is an elevated complex tombolo. It consists of two tied islands: an area to the south-west, against which Wilson Piedmont Glacier terminates, which may be either the mainland or another tied island, and connecting beaches (Figs. I and 9). Elevated beach deposits, wave-washed bedrock surfaces and marine-boulder pavements are found here. The highest parts of both tied islands are covered by beach gravels, which are approximately $15 \mathrm{~m}$ (50 ft) above sea-level. The highest point on the cape is in the south-west area. It is $20 \mathrm{~m}$ ( $66 \mathrm{ft}$ ) above sea-level and it is also veneered with beach gravels. The two tied islands were, therefore, completely submerged during the highest stand of the sea.

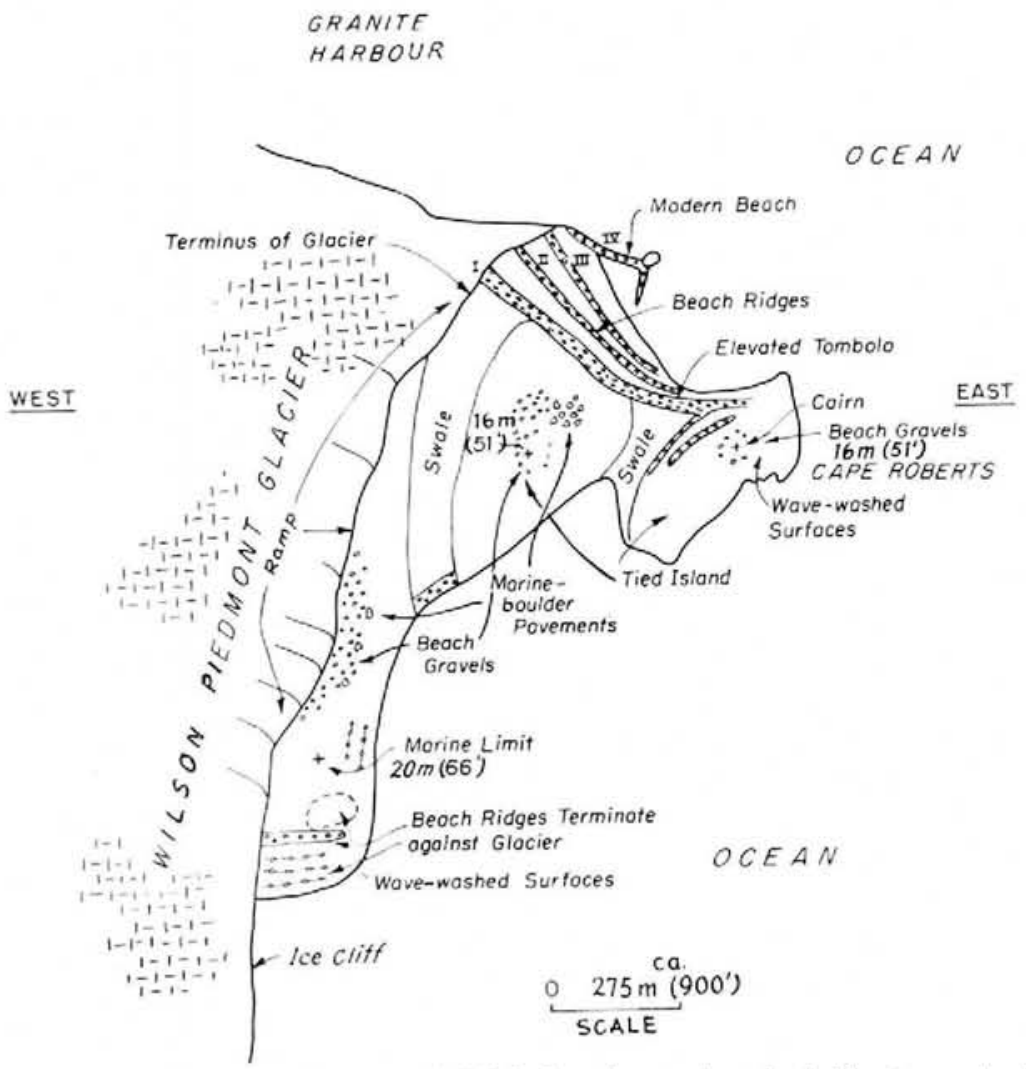

Fig. 9. Map showing the elevated beaches, wave-washed bedrock surfaces and marine-boulder pavements at Cape Roberts, McMurdo Sound.

An elevated beach approximately $16.5 \mathrm{~m}(54 \mathrm{ft})$ above sea-level meets the glacier at rightangles at the south-west corner of the cape. There is no evidence that the beach has been disturbed by a glacial re-advance. It is not known whether the beach extends beneath the glacier or only terminates against it. The latter case would indicate that it was formed when the glacier was in essentially its present position. If the beach extends beneath the glacier, a glacial re-advance has taken place since the beach was formed. If the beach does not extend beneath the ice, the terminus of the glacier may have remained in essentially its present position since the beach was formed against it, or the glacier may have retreated a certain distance after the beach was formed and later re-advanced to its present position, which it occupied when the beach was formed. 


\section{Elevated Beaches at Dunlop Island}

Dunlop Island is low-lying, flat, about $1.6 \mathrm{~km}$ ( $1 \mathrm{mile}$ ) long and $0.8 \mathrm{~km}(0.5$ mile) wide and is separated from the mainland by a narrow channel (Fig. 1). Only elevated beach gravels and elevated wave-washed bedrock surfaces are found on the island. It is essentially a low expanse of beach gravels. Ridges and swales, in places, are excellently developed; icerafted fragments of scoria and kenyte are very common, and large, well-developed frost cracks are prominent in places. The highest point, $20 \mathrm{~m}(67 \mathrm{ft})$ above sea-level (as determined by hand-level), is covered with beach gravels.

Many hectares of elevated wave-washed bedrock are found at the eastern end of the island and smaller areas are found elsewhere. No glacial striations were seen, although flat, glacially planed bedrock surfaces were noted.

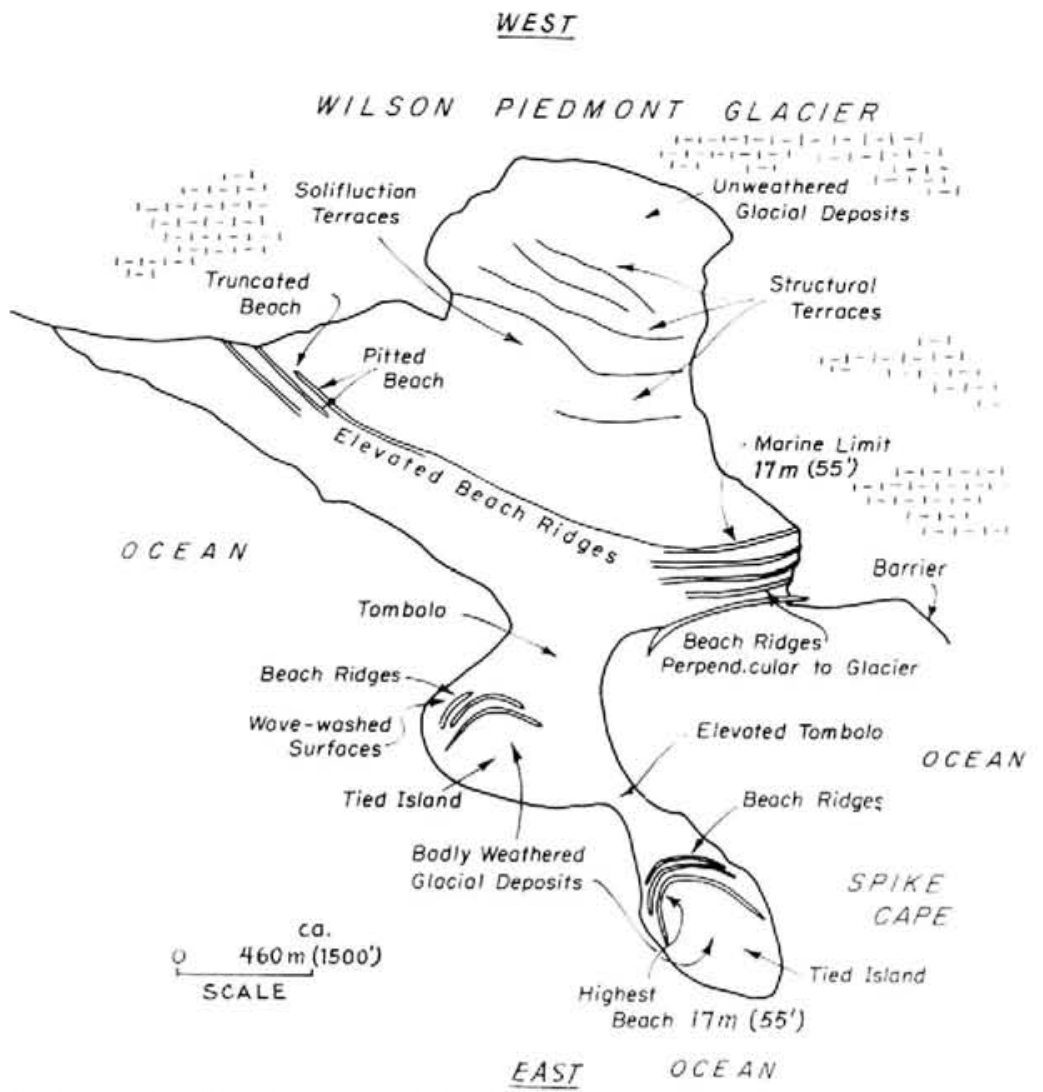

Fig. 1o. Map showing the elevated beaches, wave-washed surfaces, marine limit, and solifluction and structural terraces at Spike Cape, McMurdo Sound.

\section{Elevated Beaches at Spike. Cape}

The Spike Cape area consists of two islands tied to one another and to the mainland by tombolos (Figs. I and ro). The area of the deglaciated part of the mainland is much greater than that of the two tied islands. Excellent examples of wave-washed bedrock surfaces and well-developed beach ridges are found on both tied islands. The marine limit on the easternmost island is $17 \mathrm{~m}(55 \mathrm{ft})$ above sea-level. The glacial deposits above the marine limit on both islands are considerably weathered. Pedestal and cavernous rocks, surrounded by grains 
and fragments resulting from weathering, are common. More than $0.3 \mathrm{~m}(\mathrm{I} \mathrm{ft}$ ) of material has been removed from some fragments by weathering. Although the writer did not make a careful study of the degree of weathering of the elevated beaches and the glacial deposits above them, he believes that the beach deposits were less weathered. If true, this might suggest that an earlier series of beaches, formed immediately after the ice retreated from these islands, may have been replaced by the present beach system. A careful study of the weathering here should be made and the validity of this idea should be tested.

A well-developed series of elevated beach ridges is also found on the mainland. The highest beach at the north end of the mainland area extends approximately $17 \mathrm{~m}(55 \mathrm{ft})$ above sea-level. The beach ridges here terminate at the margin of the glacier and are perpendicular to it (Figs. 10 and 11 ). Here, as at Cape Roberts, it is not known whether the beaches extend

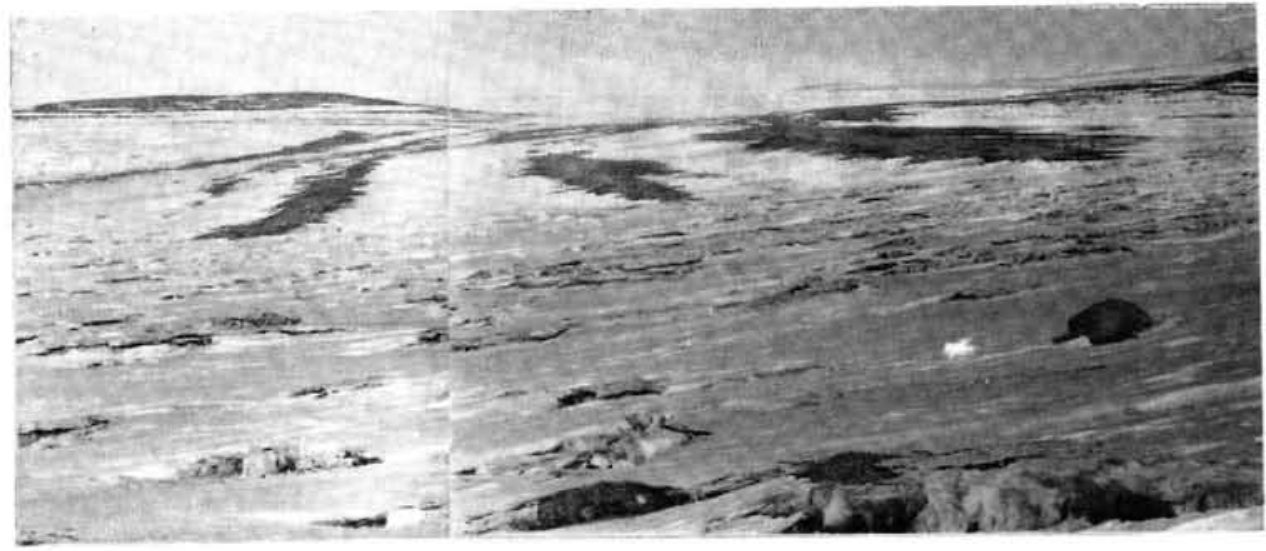

Fig. 11. Three frominent beach ridges on the mainland at Spike Cape which terminate against and are perpendicular to the margin of Wilson Piedmont Glacier. Glacier in the foreground, smow in the swales between the beach ridges in the distance.

beneath the glacier. At the southern end of the mainland, also, well-developed beach ridges terminate against the margin of the glacier. The two highest beach ridges at the southern end are pitted. The largest pits are $8 \mathrm{~m}(25 \mathrm{ft})$ across and $1 \mathrm{~m}(3 \mathrm{ft})$ deep. Although the beach ridges immediately below the highest beach ridge reach the margin of the glacier, the highest beach in the southern part of the mainland terminates between 60 and $90 \mathrm{~m}$ ( 200 and $300 \mathrm{ft}$ ) from it. There is nothing in the area where this beach ridge is not now found that indicates it was once present here but was subsequently destroyed by a glacial re-advance. Probably this beach fails to reach the margin of the glacier because the glacier occupied the area where the beach is not found while the beach was being formed elsewhere. This suggests that the beach ridges which reach the margin of the glacier do not extend beneath it, and this in turn suggests that the terminus of the glacier has been at ncarly its present position since these beaches were built.

Wilson Piedmont Glacier nearly reaches the strand line for a distance of approximately $366 \mathrm{~m}$ (400 yd) immediately south of the deglaciated mainland near Spike Cape. A gravel ridge, about $366 \mathrm{~m}$ (400 yd) long, up to $2 \mathrm{~m}$ ( $7 \mathrm{ft}$ ) high and in most places less than $9 \mathrm{~m}$ ( $30 \mathrm{ft}$ ) wide, is found at or near the strand line between the ocean and the terminus of the glacier. Although the ridge is more or less continuous, it has gaps which are tens of meters long. Elsewhere, small isolated gravel hillocks, as much as $1.2 \mathrm{~m} \mathrm{(4ft)} \mathrm{high,} \mathrm{take} \mathrm{the} \mathrm{place} \mathrm{of}$ the ridge. Pits and mounds are found on the ridge. The gravel is unweathered and somewhat sorted, and the fragments are somewhat rounded. The rounding, and the absence of morainal material on the nearby glacier, prove that the gravel is a beach deposit and not morainal 
material. It is generally only $1 \mathrm{~m}$ thick, as it rests on ice. The nearness of the glacier makes it almost certain that this ice is a stagnant piece of glacial ice. The thickness of the ice fragments immediately offshore indicates a steep offshore profile. The steep offshore profile and the snout terminus of the glacier enabled the waves to throw beach gravel onto the foot of the glacier. Following the deposition of the gravels, a small amount of glacial retreat took place. The gravels protected the ice beneath them, and an icc-cored gravel ridge with pits and hillocks was formed.

\section{Pitted Beach between Wright Glacier and Gneiss Point}

A pitted beach, in part active and in part inactive and elevated, at the mouth of the "Scheuren River" between Wright Glacier and Gneiss Point (Figs. I and 12), is approximately $600 \mathrm{~m}(2000 \mathrm{ft}$ ) in length (Nichols, $1961[\mathrm{a}],[\mathrm{b}])$. It is composed principally of poorly rounded gray gravel. In some places it is characterized by pits, hillocks and channels, and in other places it is fairly flat. The ridge-and-swale topography which characterizes most beaches is almost completely absent. Most of the channels are approximately at right-angles to the elongation of the beach. One channel was $15 \mathrm{~m}(50 \mathrm{ft})$ long, $5 \mathrm{~m}(18 \mathrm{ft})$ wide and $\mathrm{I}-2 \mathrm{~m}(3-6 \mathrm{ft})$ deep. Some pits are as much as $2 \mathrm{~m}(5 \mathrm{ft})$ deep and $6 \mathrm{~m}(20 \mathrm{ft})$ across. Thin

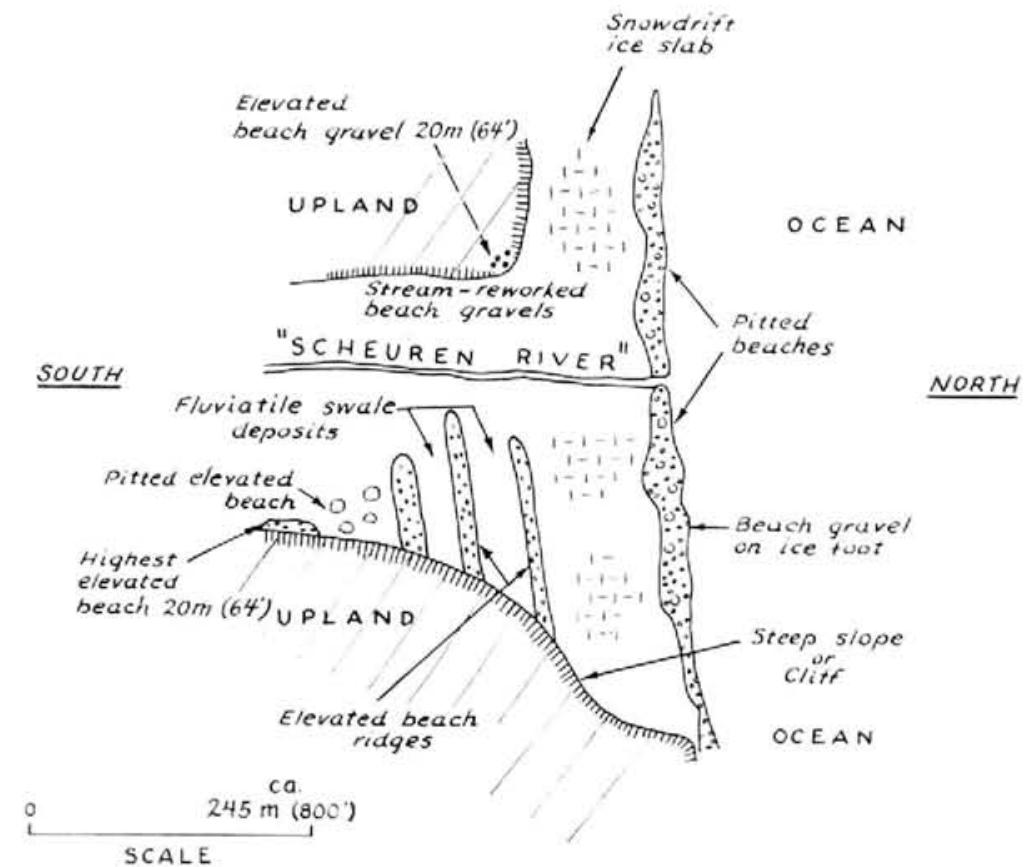

Fig. 12. A field sketch showing the pitted and elevated beaches near the mouth of the "Schenren River" between the terminus of Wright Glacier and Gneiss Point.

deposits of brown fine-grained silt and sand, in most places less than $5 \mathrm{~cm}$ (2 in.) thick, cover the gray beach gravels in some places and in other places are interbedded with them. These deposits are of fluvial and lacustrine origin, and the irregular topography on some of them proves that they are snowdrift morainal deposits. Talus blocks are found on the beach where the topography immediately behind it is steep. The innermost part of the pitted beach is slightly elevated in places. However, wave action during the summer months is modifying that part nearest the strand line. 
Immediately inland from the beach a snowdrift-ice slab slopes, steeply in some places and gradually in others, from the inner margin of the beach upward to higher ground (Fig. 13). Small ponds are dammed between this beach and the snowdrift-ice slab.

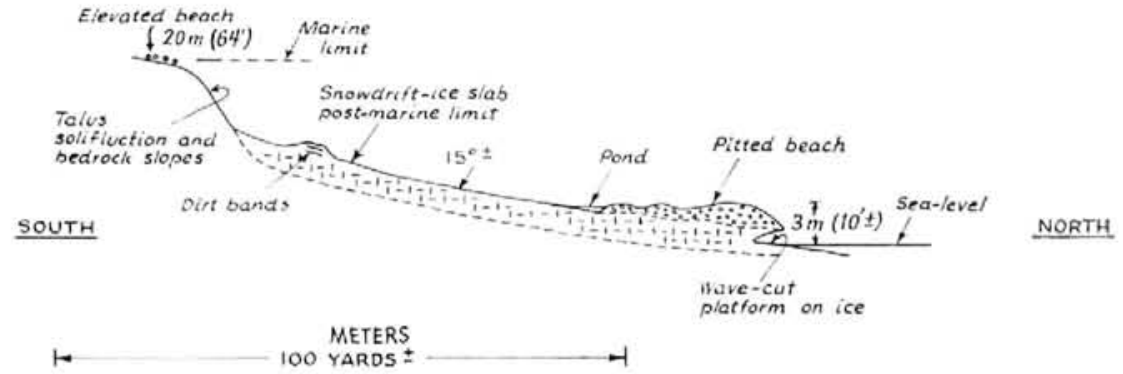

Fig. 13. Diagrammatic sketch showing the pitted beach located immediately west of the mouth of the "Scheuren River", resting on a snowdrift-ice slab.

Most, and perhaps all, of this beach has been deposited on and is even now resting on ice (Figs. 13, 14 and 15). The writer's impression was that the ice is not composed of small, disconnected numerous growlers and/or floes but is a continuous "snowdrift" ice foot. The gravel blanketing the ice, in places, is $2 \mathrm{~m}(6 \mathrm{ft})$ thick. In other places $0.5^{-1.0} \mathrm{~m}(2-3 \mathrm{ft})$ of gravel are interbedded in the ice. The interbedded gravel indicates that the ice foot took more than 1 year to form. In some places, the beach gravel appears to be thicker than the active layer and, if so, the gravel blanket protects the ice and prevents it from melting. In other places, the gravel blanket is thinner, for freshly formed cracks resulting from collapse of the gravel indicate that the ice below the gravel has recently melted.

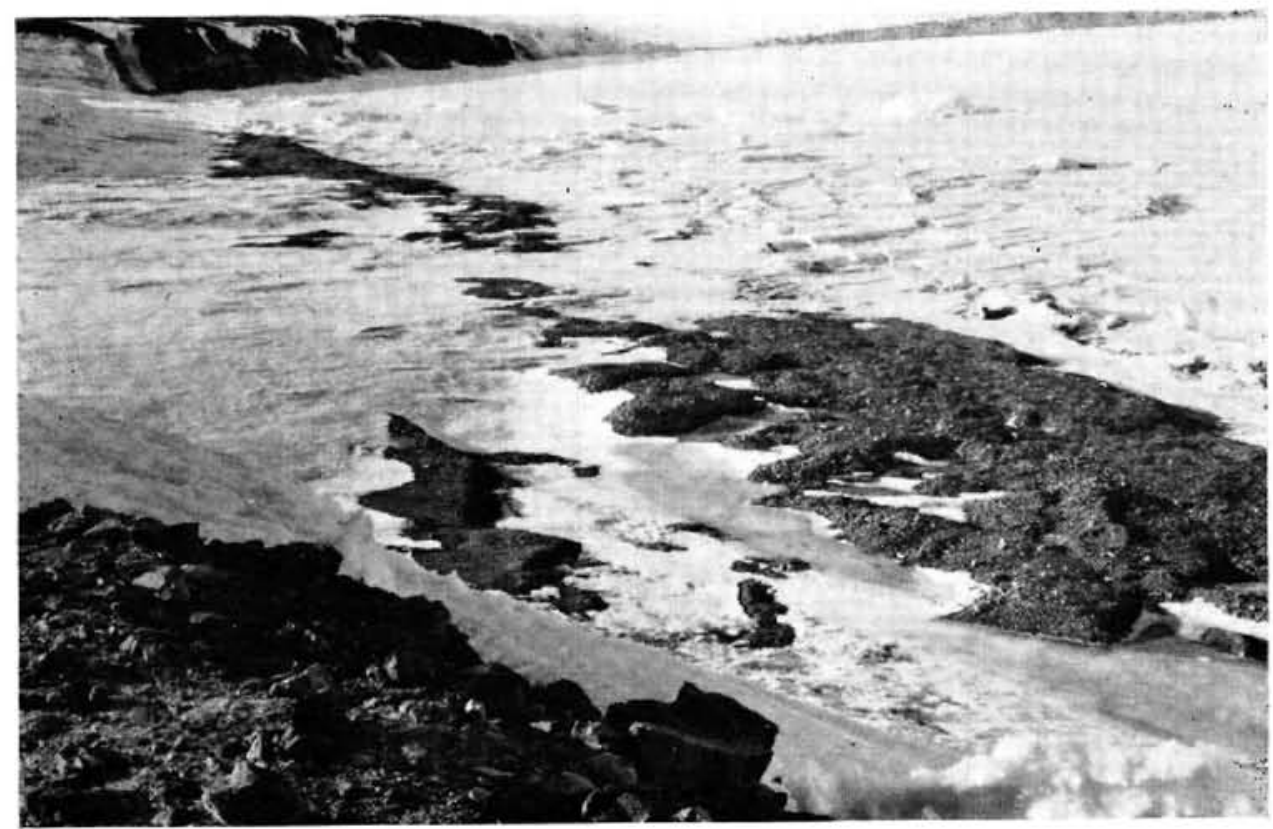

Fig. If. Photograph showing a part of the pitted beach at the mouth of the "Scheuren River" between Gineiss Point and Wright Glacier. 


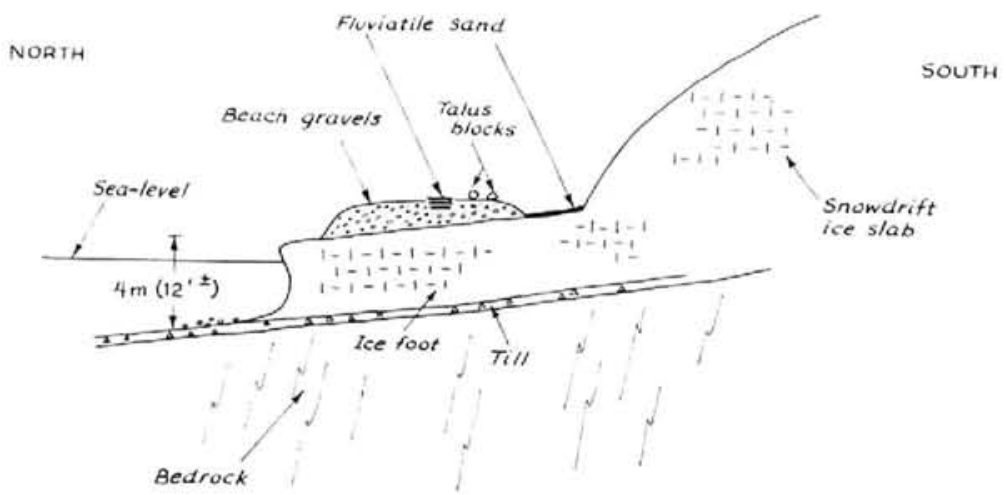

Fig. 15. Diagrammatic sketch showing beach grazels resting on an ice foot.

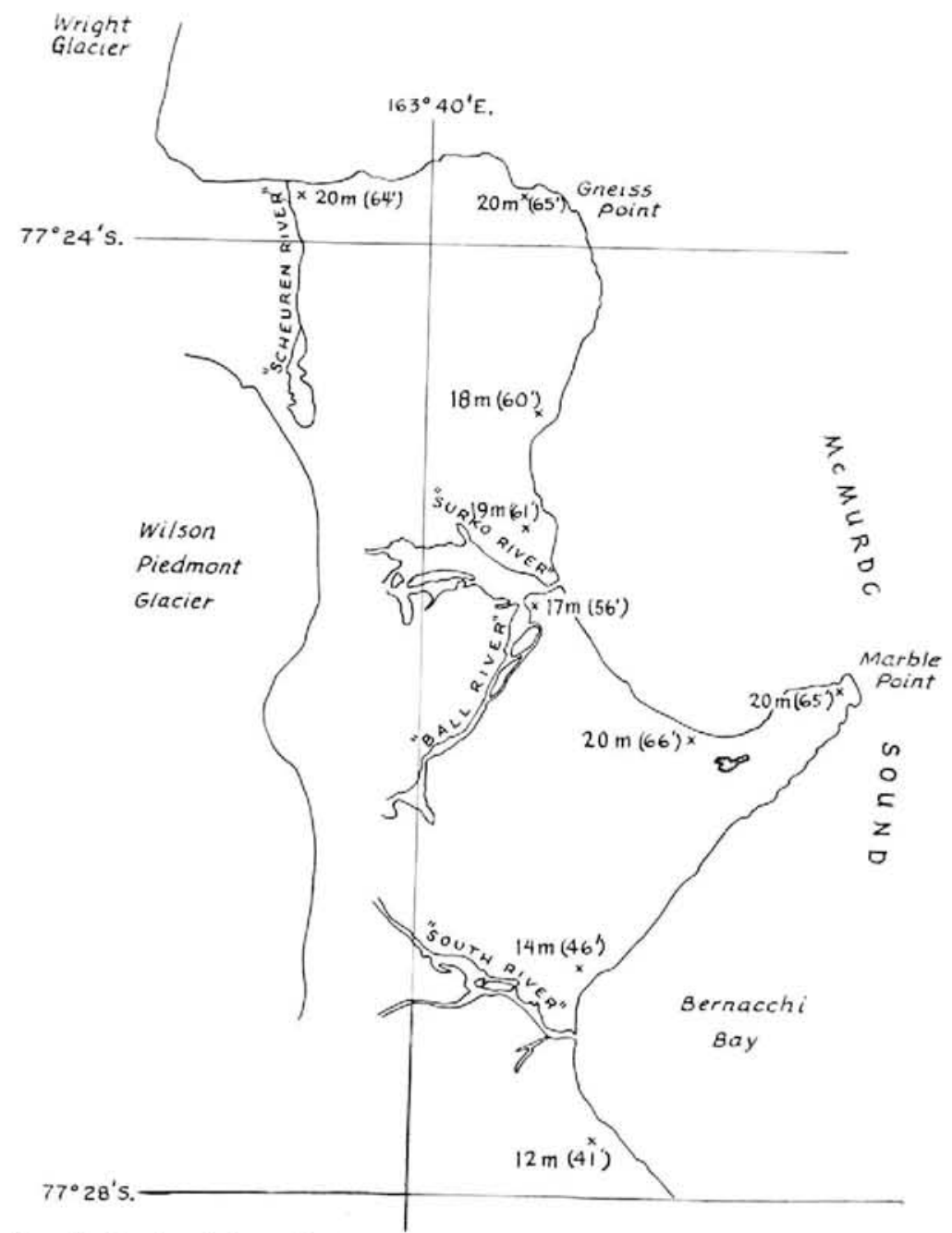

Fig. 16. Numbers indicate altitude of marine limit. Marble Point area, Mc.Murdo Sound. 
Small outlet strcams from the ponds behind the beach frequently run across the beach. These strcams are not strong enough to erode channels in the beach by removing beach gravel. However, the pond water at times is undoubtedly above $32^{\prime} \mathrm{F}\left(0^{\circ} \mathrm{C}\right)$, and it seems likely that the outlet streams have melted the icc immediatcly beneath the gravels and in this way formed the channels.

In places, the sea has undercut the gravel-veneered ice foot so that overtanging cliffs extending lor $3 \mathrm{~m}$ ( $10 \mathrm{fl}$ ) over the water have been formed (Fig. 13 ). These overhanging slabs of gravel-covered ice eventually break off and, wherc the offshore profile, the winds and the currents are favorable, they may drift away.

\section{Elfvated Beaches South of Gneiss Point}

Five prominent elevated beach ridges are excellently developed immediately south-west of Gneiss Point (Figs. I, 4 and 16 ). The marine limit here is approximately i $8 \mathrm{~m}$ (6o ft) above. sea-level (U.S. Navy Survey). Beaches I, II I, IV and V (Fig. 4) are clevated spits which al the time of their formation were attached to the north and terminated to the south-west in a shallow cove. They indicatc a south-westward movenent of material. Beach II is an elevated bay-head beach.

The beaches decrease in altitude from north-cast to south-west. Bcach 11 is $2 \mathrm{~m}$ (5 (i) lower at the head of the cove than it is $45.5 \mathrm{~m}$ (1 500 fi) to the north-cast. The beaches slope downward to the south-west because wave action decreased in strength with increased distancc into the cove, and because all spits tend to get lower toward their younger distal ends.

Beach I has well-developed prominent pits; beaches II and II have small, poorly developed pits. The pits on beach 1 are near the cove end of the beach in an area approximately $90 \mathrm{~m}$ (3oo ft) long; there are scores of them. They are sub-circular, less than $4.6 \mathrm{~m}$ (15 $\mathrm{fi}$ ) in diameler and commonly $0.3^{-0.6} \mathrm{mi}(\mathrm{s}-2 \mathrm{ft})$ deep.

Five small gravel mounds are found immediately beyond the terminus of beach $V$ and three mounds are found immediately beyond the terminus of beach IV. Thesc mounds are undoubtedly due to the deposition of gravel on or around ice which has subsequently melted. Bcach I is cut completely across near its terminus by two channels more or less perpendicular to the elongation of the beach. One channel is $22 \mathrm{~m}(73 \mathrm{ft})$ long, $7 \mathrm{~m}$ ( $24 \mathrm{li}$ ) wide and approximately $\mathrm{I} m(3 \mathrm{ft})$ decp. It seems likely that the channels were formed hy streams running across the beach from ponds which formed bchind the beach. These small streams were not capable of removing gravel but they could have molted ice beneath the gravels. Frost cracks and frost-crack polygons are also found on these beaches.

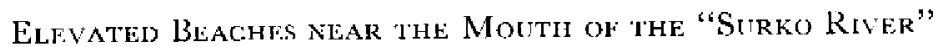

The best-developed group of bcach ridges in the area extends southward from the mouth of the "Surko River" for approximately $1070 \mathrm{~m}$ (3.500 fi) (Figs. I and 16). The group

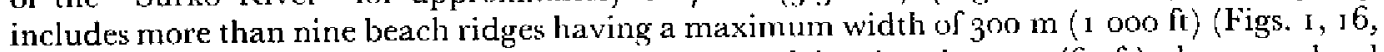
17 and 18 ). The highest beach immediately north of the river is $19 \mathrm{~m}(6 \mathrm{It})$ above sea-lcvel (U.S. Navy Survey) and the highest beach inmcdiately south of the river is $17 \mathbf{m}\left(5^{6 \mathrm{ft}}\right)$ above sea-level (U.S. Navy Survey).

The highest bcach ridge has a gap approximately $30 \mathrm{~m}$ ( $100 \mathrm{ft}$ ) long, while the beach ridgc immediately below it is continuous. The gap probably resulted from the activity of a meltwater stream derived from the glacier when it was not far distant. The absence of a gap in the next lowest beach ridge indicates that the melt-water strcam, because of glacial retreat, was no longer in existence or was no longer an effective erosive agent in this area when the lower beach ridge was formed.

The depth to frozen ground in the beach gravels on 18 Deccmber 1957 was approximatcly $0.5 \mathrm{~m}$ ( $\mathrm{r} \mathrm{in}$ ). As this was carly in the warm season, it seems likely that the active laycr in the 


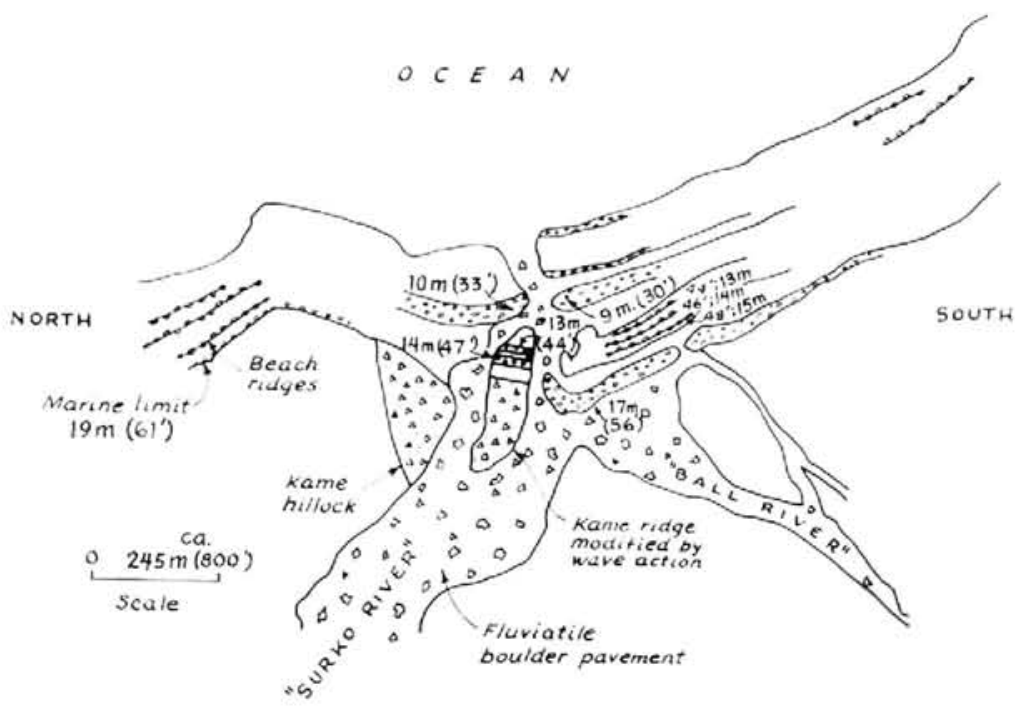

Fig. 17. Map showing the elevated beach ridges near the mouth of the "Swro River" and the kame hillock on which the highest beach ridge in this area was not deceloped. Nimbers indicate marine limit.

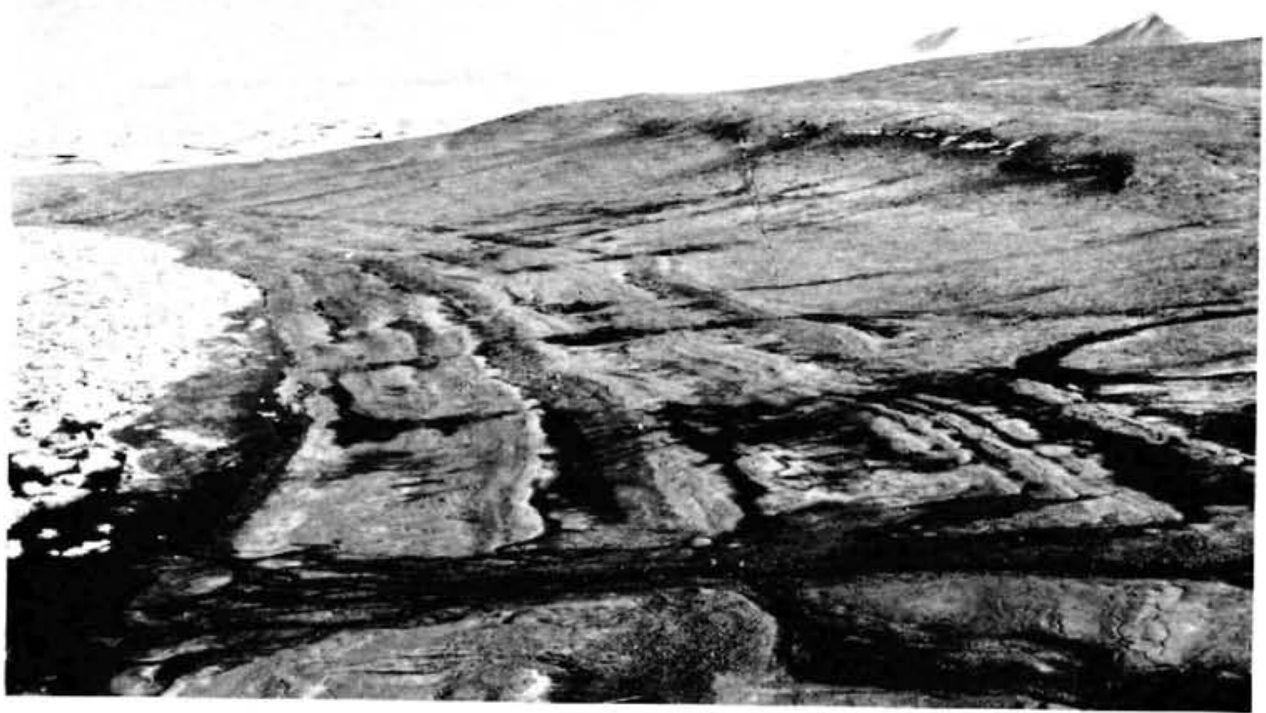

Fig. 13. Aerial photograph of the elecated beaches just south of the "Swko River". The marine limil is here approximalely $56 \mathrm{ft}$ $(17 \mathrm{~m})$ above sea-level (U.S. Navy photograph).

beach gravel is between 0.6 and $1.0 \mathrm{~m}(2$ and $3 \mathrm{ft}$ ). Large polygons resulting from the intersection of frost cracks are found on these elevated beache. In places, the cracks are nearly filled with wind-blown sand.

A kame ridge about $275 \mathrm{~m}$ (900 ft) long and $60 \mathrm{~m}(200 \mathrm{ft})$ wide, approximately $185 \mathrm{~m}$ (600 ft) from the mouth of the "Surko River" (Fig. 17), is surrounded by a fluvial boulder pavement and, during the height of the melt-water season, it is an island. Two faintly 
developed beach ridges about $30 \mathrm{~m}(100 \mathrm{ft}$ ) apart are found on its seaward side. The upper beach is approximately $14 \mathrm{~m}(47 \mathrm{ft})$ above sea-level and the lower about $13 \mathrm{~m}(44 \mathrm{ft})$ above sea-level. The highest beach ridge immediately south of the "Surko River" is approximately $17 \mathrm{~m}\left(5^{6} \mathrm{ft}\right)$ above sea-level. Closely spaced lower beach ridges are approximately ${ }_{1} 5,{ }^{1} 4$ and $13 \mathrm{~m}(48,46$ and $44 \mathrm{ft}$ ) above sea-level (Fig, 17). The two beach ridges on the kame ridge correlate, therefore, with this latter group and not with the highest beach ridge south of the "Surko River". The highest beach ridge of the area, therefore, is not found on the kame ridge. The absence of this beach ridge on the kame can be explained in one of two ways. If the kame ridge was formed rapidly where the highest beach ridge would normally have been developed, the waves and shore currents may not have had the strength to re-work the kame deposit rapidly enough to build a beach ridge. Or, if the terminus of the glacier projected out into the ocean where the kame ridge is now found, when the highest beach ridge was being formed south of the "Surko River", then no equivalent beach ridge could have been formed on the kame.

\section{Elevated Beaches at Marble Point}

The most interesting and unusual group of raised beaches in the area is at Marble Point. Here, raised beaches with the usual ridges and swales are common and so, too, are beaches characterized not by ridges and swales but by pits, hollows and mounds (Figs. 1, 16, 19 and 20).

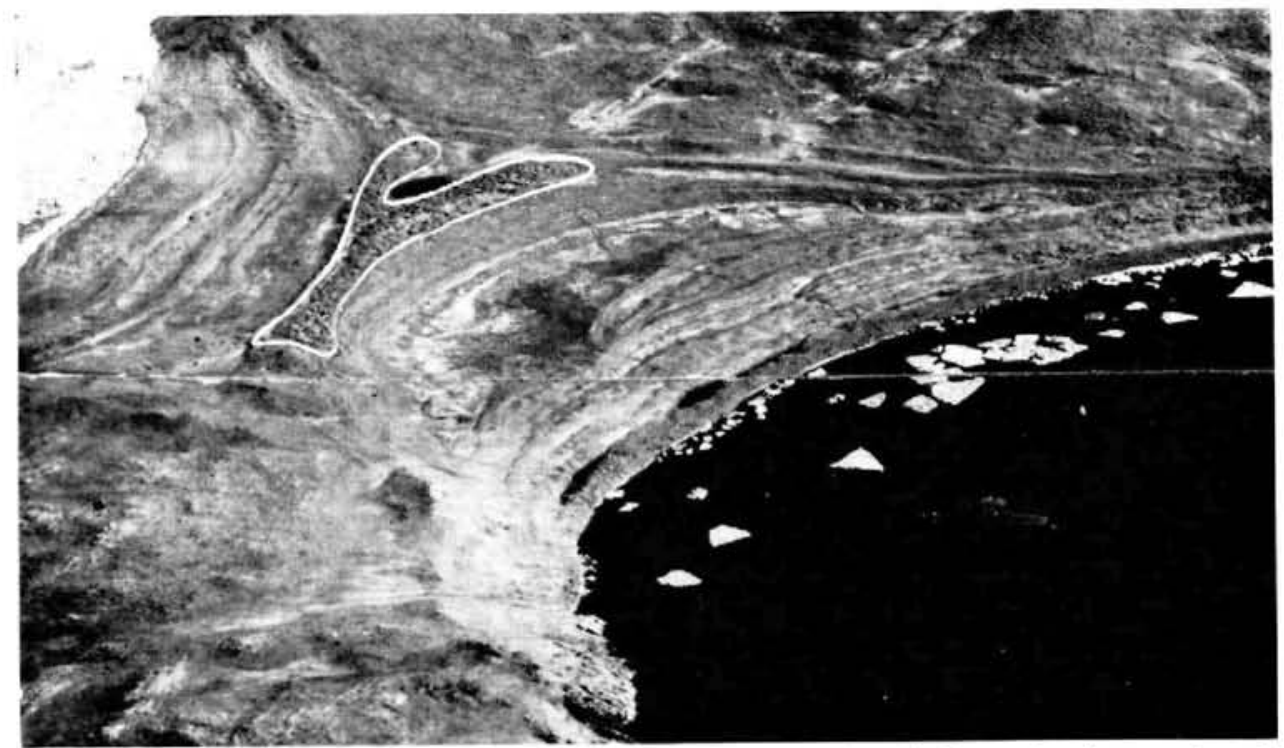

Fig. 19. Aerial photograph showing the elevated pitted beach and the elevated beaches with ridge-and-swale lopography at Marble Point. The pitted beach is located in the area enclosed by the while lines. The marine limit is $66 f t(20.1 \mathrm{~m})$ above sealevel (U.S. Naxy photograph).

The area containing the pits is about $455 \mathrm{~m}$ ( $1500 \mathrm{ft}$ ) long and $60-120 \mathrm{~m}$ (200-40o ft) wide. It is, in general, between 14 and $17 \mathrm{~m} \mathrm{(45} \mathrm{and} 55 \mathrm{ft}$ ) above sea-level, and it contains hundreds of pits (Figs. 7, 19 and 20). They are round, oblong or irregular. Although most of the pits are single, two or more may coalesce and form compound pits. The single pits range in diameter from 4 to $12 \mathrm{~m}$ ( 13 to $40 \mathrm{ft}$ ). One oblong compound pit is $35 \mathrm{~m}$ ( $115 \mathrm{ft}$ ) long. Most of the pits are less than $1.3 \mathrm{~m}(4 \mathrm{ft})$ deep, although some are as much as $2 \mathrm{~m}(6 \mathrm{ft})$ deep (Fig. 7). Most of the pits are dry but a few contain water. 
Black sand immediately underlies a veneer of light-colored sand in the bottom of one of the pits. The black color disappeared when the sediment dried, indicating that the color is not due to finely divided organic matter but to finely divided iron pyrite (Johnson, 1925, p. 57 I-72; Twenhofel, 1932, p. 155, 450, 451; Barghoorn and Nichols, 1961, p. 190).

The pitted beach resembles pitted outwash but the following facts prove that the pitted area is an elevated beach and not outwash. (I) No significant topographic break exists between the pitted beach and the lower adjoining elevated beaches which are characterized by ridges and swales. (2) The sand and gravel in the pitted area are similar to sand and gravel in the elevated beaches characterized by ridges and swales. (3) An active beach with the same pitted topography is found near the mouth of the "Scheuren River". (4) The bifurcation of the mainland side of the pitted area is what would be expected if this area were an elevated beach (Fig. 19). (5) The pitted area is below the marine limit. (6) The material in the pitted beach is much better sorted than outwash.

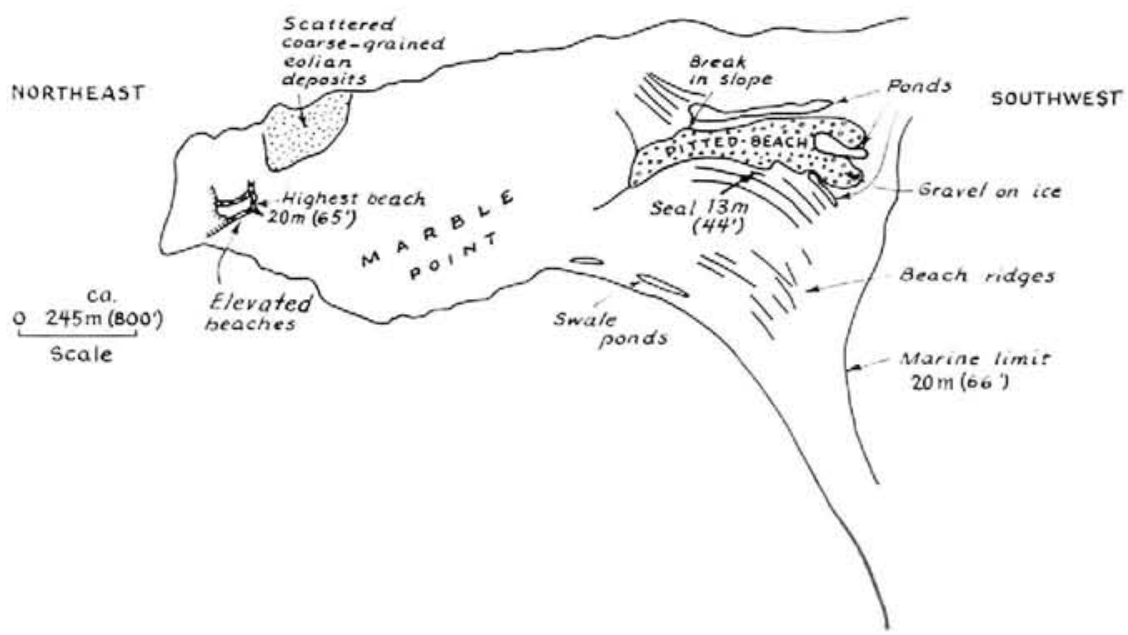

Fig. 2o. Map showing the distribution and altitude of the elevated beaches at Marble Point, McMurdo Sound.

A hole was dug into the gravels in a mound in the pitted area. Clean ice was encountered at a depth of approximately $50 \mathrm{~cm}(20 \mathrm{in})$. The ice was penetrated to a depth of $110 \mathrm{~cm}$ (43 in) and the bottom of it was not reached. Another hole was dug in the pitted topography about $7 \mathrm{~m}(22 \mathrm{ft})$ away. Ice was encountered at $38 \mathrm{~cm}\left(\mathrm{r}_{5} \mathrm{in}\right)$ and the bottom of the ice was not reached. Only a very minor amount of sand was found in the ice.

Later, the U.S. Navy, in carrying out engineering studies, removed with a bulldozer between 0.3 and $0.6 \mathrm{~m}$ ( $\mathrm{l}$ and $2 \mathrm{ft}$ ) of sand and gravel from a part of the elevated pitted beach. Hand-digging in the bulldozed area showed that a layer of pure ice was present beneath the sand and gravel in an area $185 \mathrm{~m}(600 \mathrm{ft})$ long and $21 \mathrm{~m}(70 \mathrm{ft})$ wide, and was probably present beneath most of the beach. The U.S. Navy blasted a hole in this ice (Fig. $2 \mathrm{I}$ ) and this showed that the ice is essentially clean. $2-3 \mathrm{~m}\left(7^{-8 \mathrm{ft}}\right)$ of the ice was penetrated but the bottom was not reached. Digging showed that the surface of the ice slab had a relief of at least $0.6 \mathrm{~m}(2 \mathrm{ft})$. Additional digging would probably have revealed a somewhat greater maximum relief but not a significantly greater relief. The digging also showed that the surface of the ice is low beneath pits and high in the areas between pits. The writer believes that the ice was not made up of isolated unconnected fragments, but it was a continuous and essentially flat-topped ice foot, 
A well-developed series of beaches with ridge-and-swale topography extends from the lower limit of the pitted beach, on both its north and south sides, down to the present-day sea-level. These beaches, as far as is known, were not deposited upon an ice foot.

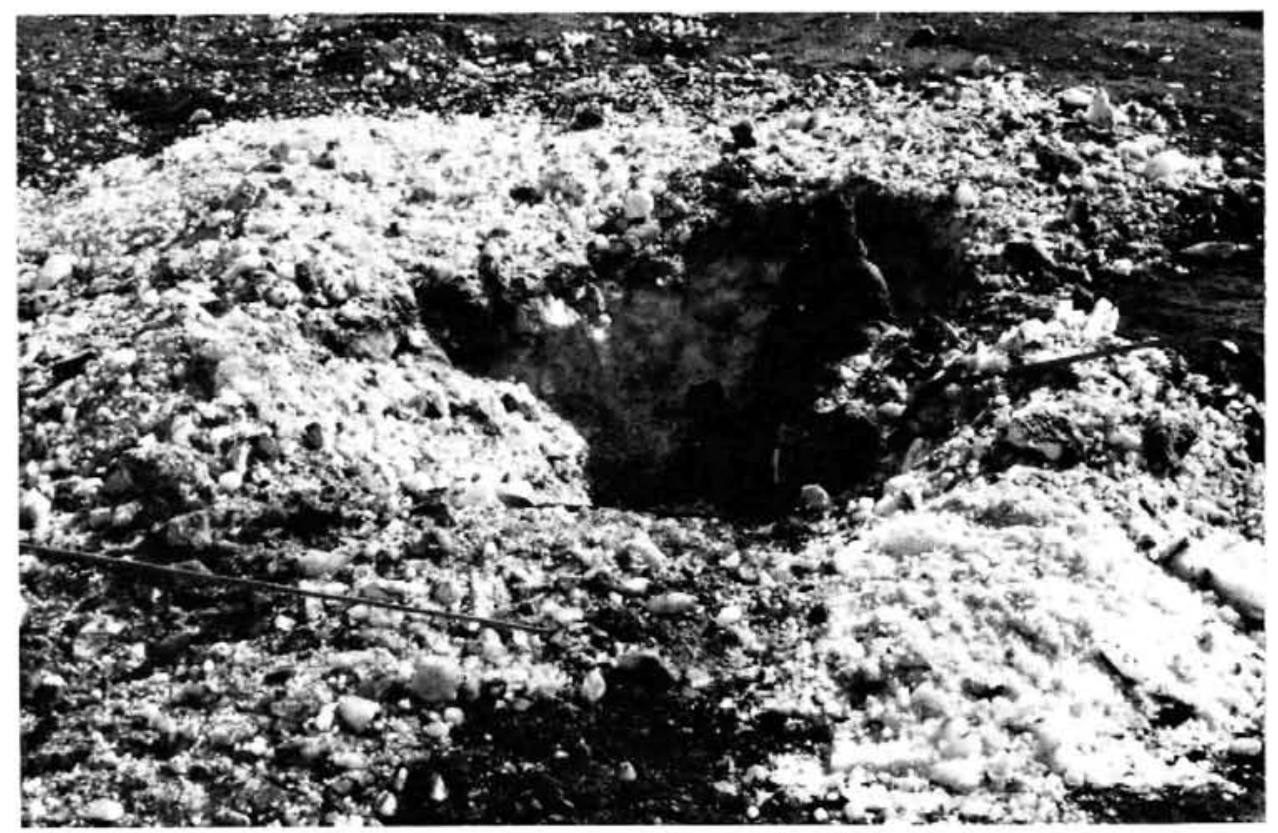

Fig. 2I. A hole blasted through elevated pitted beach gravels at Marble Point aptroximately $14 \mathrm{~m}$ ( $4.5 \mathrm{ft}$ ) aboic sea-level and into the ice foot on which they were deposiled. The beach gravels were thick enough to preserve the ice foot during a period in which the Earth's crust rose approximately $14 \mathrm{~m}(45 \mathrm{ft})$ with respect to sea-level.

The highest beach in this area is about $20 \mathrm{~m}(66 \mathrm{ft})$ above sea-level (U.S. Navy Survey) and between 3 and $6 \mathrm{~m}$ ( 10 and $20 \mathrm{ft}$ ) above the pitted beaches. It is not pitted. At the time the sea was at this position and before this beach was formed, Marble Point (now a peninsula) did not exist; in its place was a bedrock island about $9^{1} 5 \mathrm{~m}(3000 \mathrm{ft})$ long and $460 \mathrm{~m} \mathrm{(} 5^{\circ 0 \mathrm{ft}}$ ) wide, which was separated from the mainland to the west by approximately $460 \mathrm{~m}$ ( $5^{00 \mathrm{ft}}$ ) of shallow water. Sea-level slowiy dropped following the formation of this beach and a large ice foot was formed. This ice foot was approximately $460 \mathrm{~m}$ ( $\mathrm{t} 500 \mathrm{ft}$ ) long from east to west, $61 \mathrm{~m}$ (200 ft) wide from north to south at its eastern end and $122 \mathrm{~m}$ (400 ft) wide at its western end. It tied the island to the mainland. Following the formation of the ice foot, a layer of

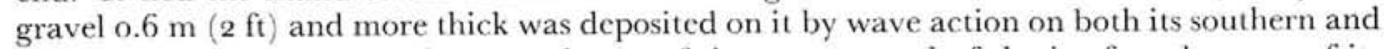
northern sides. However, the central part of the western end of the ice foot, because of its great width, was either not buried or only thinly buried (Fig. 20). Following this, sea-level dropped slowly to its present position and a series of lower elevated beaches with the normal ridge-and-swale topography developed.

Meanwhile, that part of the ice foot which had not been veneered or had been only thinly veneered with gravel melted away, leaving a depression. Where the gravel veneer was somewhat thicker, some of the ice below it melted and the pitted area was formed. An elevated pitted beach which bifurcates near the mainland to the west was thus formed.

This is an interesting example of ice-foot permanence, considering its age. It is preserved due to the thickness of the protecting blanket of sand and gravel. Had the gravel been everywhere $1.3 \mathrm{~m}$ ( $4 \mathrm{ft}$ ) or more thick, the ice foot would have been preserved without any melting 
if the climate since its formation had been at no time warmer than at present. In this event no pits and hollows would have been formed.

A complete skeleton was found buried at Marble Point in beach gravels $13 \mathrm{~m}(44 \mathrm{ft})$ above sea-level (U.S. Navy Survey) and about $305 \mathrm{~m}$ ( $\mathrm{t}$ ooo ft) from the present shoreline. Barbara Lawrence, of the Museum of Comparative Zoology, Harvard University, has identified the skeleton as that of an elephant seal. It was approximately $3 \mathrm{~m}$ ( $10 \mathrm{ft}$ ) long (Fig. 22). The

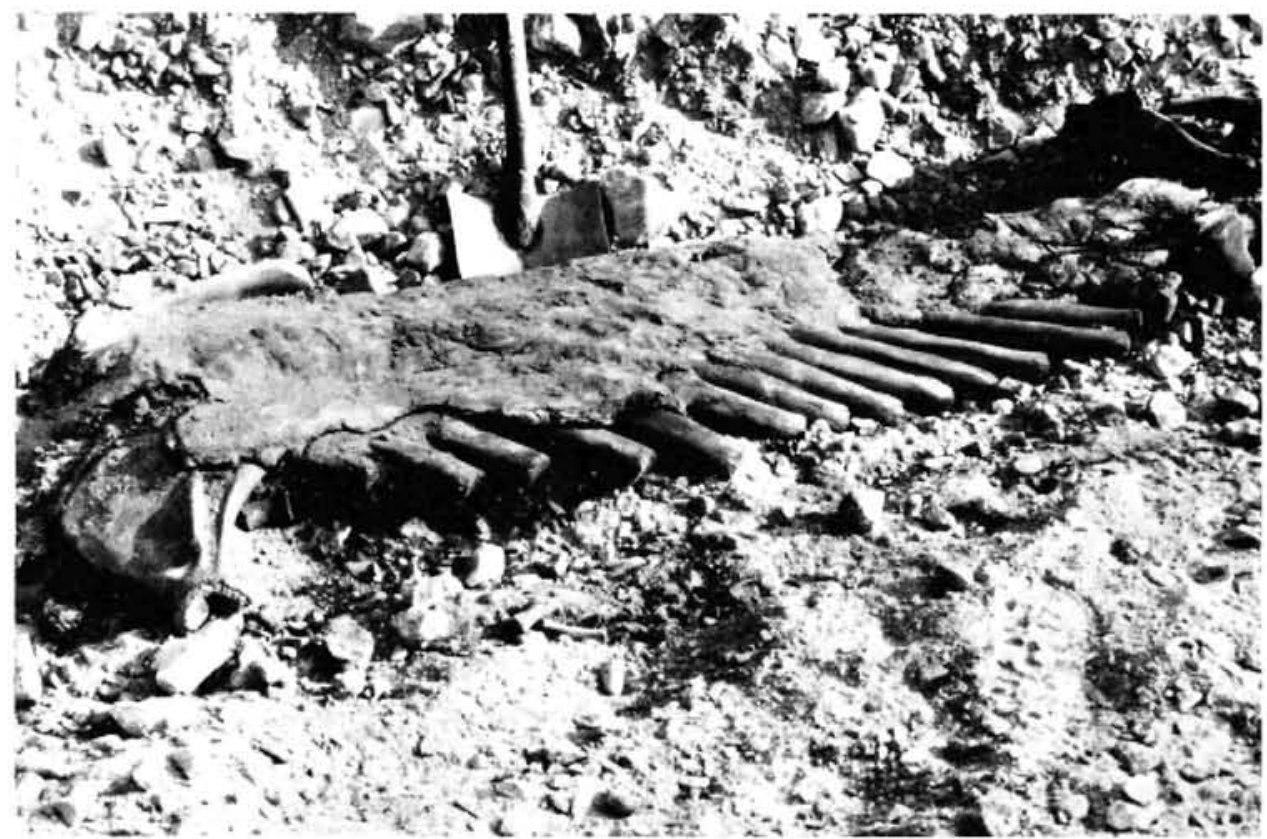

Fï. 22. An elephant-seal skeleton $3 \mathrm{~m}$ ( $10 \mathrm{ft}$ ) long which was buried at Marble Point in beach gravels now $13.4 \mathrm{~m}(4.4 \mathrm{fl})$ aboie sea-level and approximately $305 \mathrm{~m}$ (1 0oo fl) from the modern strand line. Dried shin covers a part of the skeleton.

bones were almost entirely chocolate brown. A very small part of the skeleton, however, which was perhaps not buried, had been bleached white. Dried-out hide covered the spinal column and parts of the ribs. Hair was found on the lower but not on the upper side of the skeleton. A very slight odor was noticcable.

Although elephant seals can crawl for considerable distances above sea-level, they cannot bury themselves in beach gravel. This elephant seal, therefore, must have been buried by wave action shortly after its death. The beach where the skeleton was found has a very flat profile, and this, together with a consideration of the size and weight of the animal, indicates that it must have been buried very close to the high-tide mark. The age of the seal, and therefore of the beach, as determined by a radiocarbon-age analysis is $445^{\circ}+15^{\circ}$ years (Olson and Broecker, $196 \mathrm{t}$, p. 150 ). The highest beaches are prinaps a few thousand years older. They roughly correlate, on the basis of their degree of weathering and crosion, with the Trilogy deposits in the Wright Valley (Nichols, $1961|c|$ ) and therefore they post-date the youngest glaciation of the area.

There is as yet no good agreement concerning the changes of sea-level during the past 5000 years. However, the latest ${ }^{4} \mathrm{C}$ dates of organisms and plants that lived close to sea-level in relatively stable areas indicate that $445^{\circ} \pm 15^{\circ}$ years ago, when the elephant seal at Marble Point was buried with beach gravels by wave action, sea-level the world around was approximately $3 \mathrm{~m}$ ( $10 \mathrm{ft}$ ) lower than at present (Shepard, 1964 ). This indicates that the Marble Point area has risen isostatically about $\mathrm{I} 6 \mathrm{~m}(54 \mathrm{ft})$ during the last $445^{\circ} \pm \mathrm{I} 5^{\circ}$ years. 


\section{Elevated Marine Deposits near the Mouth of the "South River"}

The marine limit immediately north of the "South River" is approximately $14 \mathrm{~m}(46 \mathrm{ft})$ * above sea-level (hand-level survey) (Figs. I, I6 and 23). The marine limit about $0.8 \mathrm{~km}$

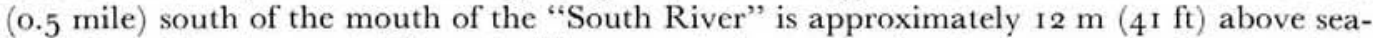
level (hand-level survey) (Fig. 23). These are the lowest marine limits measured in the whole
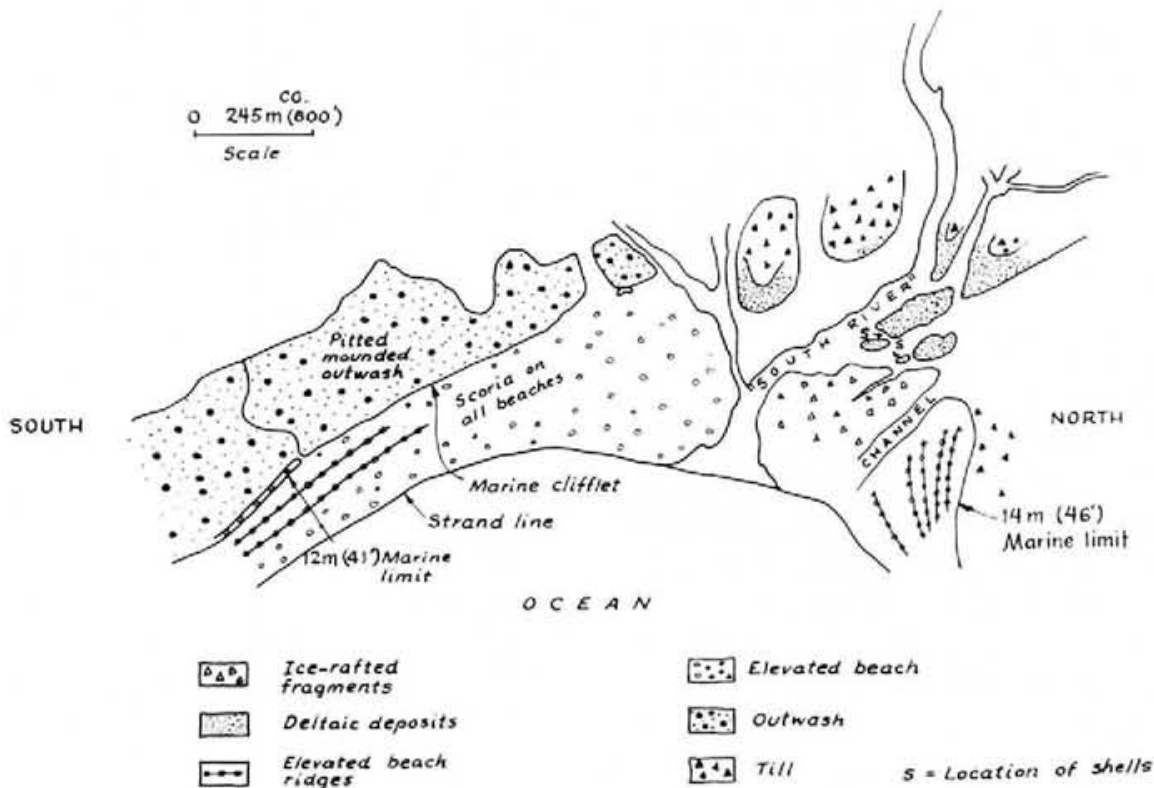

Fig. 23. Map showing the elevated beaches, the pitted and mounded outwash, and the dissected uplifled deltaic deposits near the mouth of the "South River".

area. It is not known whether they are due to a southward tilt of the marine limit, to a delayed retreat of the glacier in this area, or, in the case of the $12-\mathrm{m}(4 \mathrm{I}-\mathrm{ft})$ marine limit, to a rapid deposition of considerable quantities of outwash after the glacier retreated from this area, which prevented the development of the higher beaches.

A broad expanse of elevated beaches, more than $305 \mathrm{~m}$ ( 1 ooo ft) wide, is located immediately south of the "South River" (Fig. 23). Ice-rafted scoria is more common on these beaches than on those farther north, because they are closer to the sources of the scoria. Immediately above these beaches is a large area of pitted and mounded outwash. A small marine cliff has been cut in the outwash and an elevated bay-mouth beach is attached to it on the south. Topographically, there is little to differentiate this pitted outwash from pitted beaches. However, identification is made certain by the absence of scoria on the outwash, by the presence of silt in these deposits and by the marine cliff cut in them (Fig. 23).

Three small mesas composed of sediments are found near the mouth of the "South River" (Fig. 23) (Nichols, 1963 [b]). The highest point on these mesas is approximately $11 \mathrm{~m}(35 \mathrm{ft})$ above sea-level (hand-level survey), and they stand as much as $5 \mathrm{~m}$ ( $15 \mathrm{ft}$ ) above the bottom of the channels which separate them. They have been formed because of the dissection of a continuous blanket of deposits by the "South River". These deposits are composed mainly of sand and silt, and more than $5 \mathrm{~m}$ ( ${ }_{5} \mathrm{ft}$ ) of them are exposed. They are stratified, ripplemarked and cross-bedded, and they slope gently seaward.

* Owing to a snow cover on land and to the presence of sea ice and growlers, this figure may be somewhat in error. 


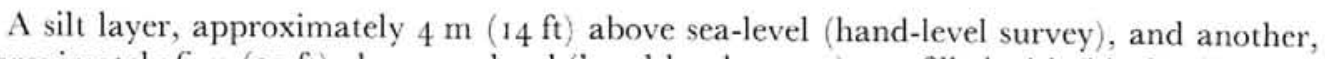
approximately $6 \mathrm{~m}(2 \mathrm{Ift})$ above sea-level (hand-level survey), are filled with thin fragile shells (Fig. 23). Dr Arthur H. Clarke, Jr., of the National Museum of Canada, Ottawa, has identified them as Adamussium colbecki (Smith $\mathrm{rgO2}$ ). This is an abundant circum-Antarctic pecten which has been found living in water from 4 to $700 \mathrm{~m}$ ( 13 to $2300 \mathrm{ft}$ ) deep (Soot-Ryen, I951, p. 16-19).

The fine-grained nature of the sediments in which the shells are found and the distribution of Adamussium colbecki indicate that they are uplifted, shallow-water offshore deposits. An uplift of more than $6 \mathrm{~m}(2 \mathrm{It})$ is indicated.

The mesa sediments extend up to 1 i $\mathrm{m}(35 \mathrm{ft})$ above sea-level. The surfaces of the mesas, like the sediments, slope gently seaward. Gravel is found on these surfaces but not scoria. These facts suggest that the lower, fincr-grained mesa sediments are the marine facies of a delta of the "South River", and that the upper coarser-grained sediments are the subaerial facies of the delta. Inland from the mesas are several patches of gravel similar to that found on the tops of the mesas. These patches undoubtedly were once continuous with the gravel on the mesas.

An elevated surface, sloping gently seaward and separated from the nearby mesas by abandoned channels, is located immediately seaward from the mesas. This surface, at its highest point, is more than $7 \mathrm{~m}(24 \mathrm{ft}$ ) above sca-level (hand-level survey). Beach ridges and swales are not found on it, but the abundant ice-rafted scoria and other kinds of ice-rafted fragments prove the marine origin of both the surface and the sediments immediately beneath it. This surface stands out in sharp contrast to those on the mesas; it is covered with a great abundance of large, ice-rafted angular fragments, whereas the surfaces of the mesas are almost devoid of them (Fig. 23). This supports the belief that the deposits on top of the mesas are subacrial and the deposits on top of the sloping surface are marine.

The marine limit, therefore, is lower at the mouth of the "South River" than it is immediately north and south of the river. The marine limit would be lower at the mouth of the "South River" if the Wilson Piedmont Glacier projected farther seaward here at the time the marine limit was being formed. Precisely such an extension would be expected because the glacier would be thicker and therefore moving forward faster in the valley than elsewhere.

\section{Beaches between Cape Bernacchi and Cape Chocolate}

Beach deposits up to approximately $12 \mathrm{~m}$ (40 $\mathrm{ft}$ ) above sea-level are found at Cape Bernacchi (Fig. 24). Immediately above this material, solifluction deposits occur. If any higher beaches were ever formed here, they are therefore buried by solifluction deposits. Water-washed and water-rounded bedrock surfaces that are probably due to wave action are found immediately below.

Less than $1.6 \mathrm{~km}$ ( $\mathrm{I}$ mile) south of Cape Bernacchi, a well-developed beach ridge $5 \mathrm{~m}$ ( 7 ft) above sea-level was noted (Fig. 24), and the marine limit may be even higher here. Approximately $3 \mathrm{~km}$ ( 2 miles) south of Cape Bernacchi on the north side of "Broad Delta Bay" a boulder beach approximately $3 \mathrm{~m}(9 \mathrm{ft}$ ) above sea-level is found. This beach can be identified by the very large boulder on it (Fig. 24). Still farther towards the head of "Broad Delta Bay" a beach ridge approximately $2 \mathrm{~m}(6 \mathrm{ft})$ above sea-level is found (Fig. 24). At the head of "Broad Delta Bay" morainal topography unmodified by wave action extends down to the modern shoreline, and the coastline is irregular because no straightening by wave action has taken place.

On the south side of "Broad Delta Bay" north-west of the eastern end of the Kukri Hills (Fig. 24) an alluvial apron is found along the coast. A line of rounded boulders approximately $3 \mathrm{~m}$ (10 ft) above sea-level and parallel to the shoreline protrudes above the alluvial apron. The boulders are more rounded than the fragments on the moraine immediately 
inland from the alluvial apron. It is unlikely that they were rounded by the melt water which deposited the alluvium, as they protrude $0.5 \mathrm{~m}$ ( $\mathrm{r} 8 \mathrm{in}$ ) above it. They may have been rounded by wave action and, if so, indicate a small amount of uplift. Although a careful search was made for raised beaches, none were found between these boulders and Cape Chocolate, and there is no other evidence here that sea-level was higher than now at any time since the last deglaciation of the area. $0.8 \mathrm{~km}(0.5$ mile) south of Blue Glacier (Fig. I) there is a marine cliff approximately $9 \mathrm{~m}(3 \circ \mathrm{ft})$ high. $1-3 \mathrm{~m}\left(3^{-10 \mathrm{ft}}\right)$ of topset beds crop out in the upper part of the cliff, and there are more than $6 \mathrm{~m}(20 \mathrm{ft})$ of glacial ice immediately below these beds. These foreset beds, although found on the coast, do not indicate uplift, as they werc formed in a kettle-hole pond which rested on ice (Nichols, 1966, p. 27).

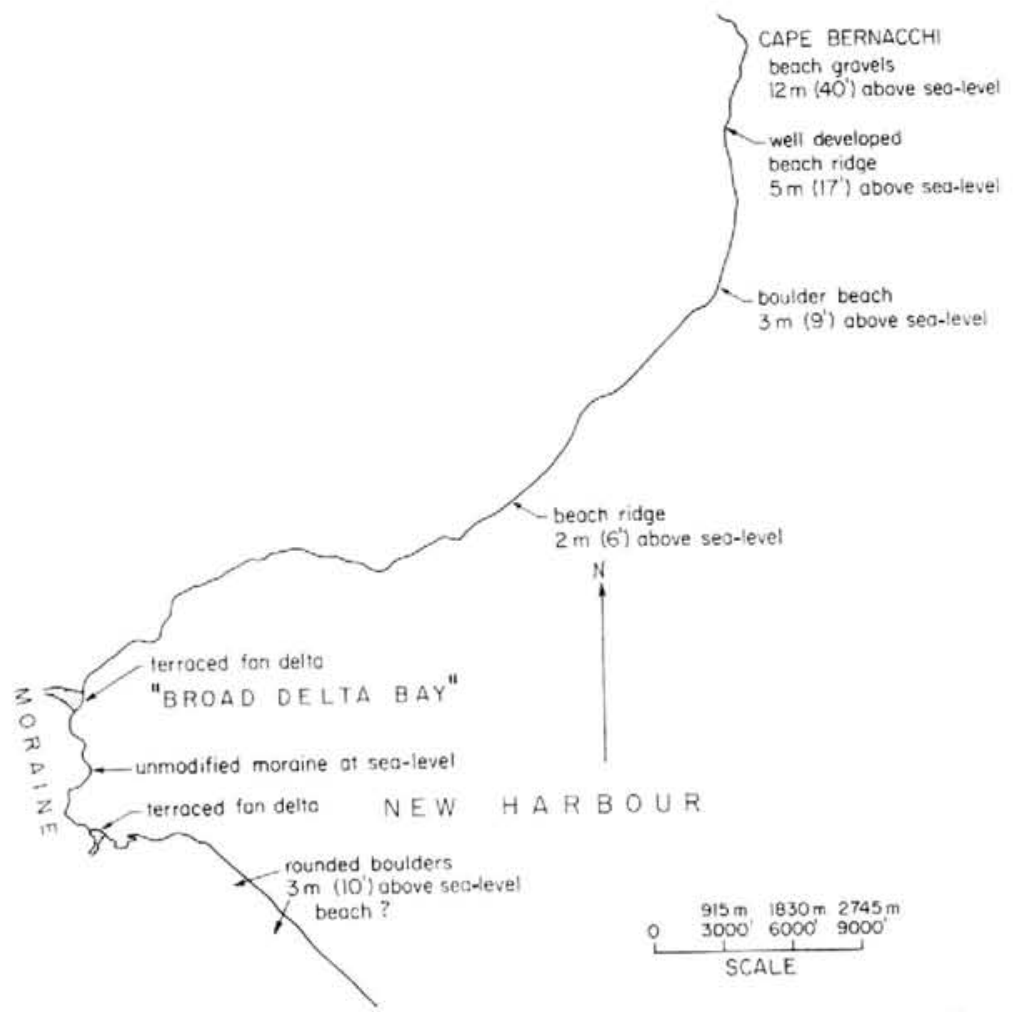

Fig. 2f. A map showing the location of the elevaled beaches in "Broad Della Bay".

At the head of "Broad Delta Bay" Priestley found what he thought was a raised beach (David and Priestley, I914, p. 273; Wright and Priestley, 1922, p. 442-43; Priestley, 1923, p. 56-57). He wrote: "At the seaward end of the Dry Valley of the Taylor Glacier, one of the writers found a gradually sloping beach in which numerous shells of Pecten colbecki and Anatina elliptica and of Lima together with other organic remains, such as the legs of Decapods and other crustacea, were embedded in considerable numbers up to $9^{-12} \mathrm{~m}[30-40 \mathrm{ft}]$ above sea level at least. The greater portion of the immediate surface deposit at this spot consisted of fine silt distributed by the thaw-water of the streams from glaciers further up the valley. Where these streams had cut down several centimetres [a few inches] into the marine deposits of the beach, however, the fragments of marine organisms were numerous, and there can be no doubt at all that here, at the entrance to the Taylor Valley, a true recent elevation of the land has taken place." 
The writer investigated the area. The feature Priestley described is an alluvial fan, not a raised beach. This is proved by the following: (I) Immediately up-stream from the feature there is a sizable ravine, in which a melt-water stream flows during the summer months. (2) There are no raised beaches in adjacent areas. (3) Beach ridges and swales are not found on the feature. (4) It is fan-like in shape.

The marine organisms buried in the fan, as much as $9-12 \mathrm{~m}(30-40 \mathrm{ft})$ above sea-level, may be explained in two ways. First, they are light and could easily have been transported by wind. Moreover, Priestley wrote that all of the organisms are shallow-water forms. It seems likely, therefore, that these organisms could have been deposited on the modern beach by waves, blown by wind up onto the fan and buried by the deposition of alluvium on the fan by meltwater streams. Secondly, the moraine at the head of "Broad Delta Bay" could contain marine organisms if it had been deposited by a glacier that moved across McMurdo Sound (Nichols, 1965, p. 441). Such a glacier could pick up marine deposits and organisms from the bottom of McMurdo Sound and glacial deposition would result in a fossilifcrous moraine. Erosion by melt-water streams could result in alluvial fans that contained marine organisms. The presence of deep-water marine organisms in Priestley's fan could probably be explained only by this mechanism. Morcover, the presence of only broken fragments of the marine organisms in the fan also favors this explanation. As far as the writer knows, no marine organisms have been found in the moraine at the head of "Broad Delta Bay". They should be looked for. In this connection it is interesting to note that Professor T. L. Péwé, Arizona State University, collected some pectens near the modern high-tide mark on a beach at the end of Taylor Dry Valley (lat. $77^{\prime} 35^{\prime} \mathrm{S}$, long. $163^{\circ} 30^{\prime}$ E.). These pectens were found to be $4000=200$ ycars old by the Lamont Geological Observatory, Columbia University, Palisades, New York (Olson and Broecker, 1961 , p. $149-50)$. If these shells were eroded from the moraine at the head of "Broad Delta Bay"-and their age suggests this as a possibility then the Koettlitz glaciation was a little more extensive than Péwé (1960, fig. 8 ) originally thought.

A fan delta is located on the south side of "Broad Delta Bay" (Fig. 24). It is found immediately down-stream from a ravine cut in the large moraine at the mouth of Taylor Valley. The ravine and fan were formed by the melt-water stream that runs during the summer season from the bottom of the ravine across the fan. A series of non-paired fluvial terraces have been cut in it. It terminates on its seaward side in a marine clifflet about $1 \mathrm{~m}(3 \mathrm{ft})$ high, the base of which is approximately at present-day storm-tide level. The exact position of sealevel when the fan was formed is not known, as no topset beds were seen. However, the absence of raised beaches in adjacent areas suggests that the fan was formed at approximately the present position of sea-level. Moreover, the absence of raised beaches in the areas adjacent to the fan indicates that the dissection of the fan and formation of the terraces were not due to uplift. Perhaps with the passage of time the stream at the bottom of the ravine became underloaded because less and less material was furnished to it. This would have resulted in the dissection of the fan and in the formation of non-paired terraces. Similar fan deltas are found south of Blue Glacier, on the north side of "Broad Delta Bay" and elsewhere.

Speden (1960), in an interesting and instructive paper, has described a similar fan delta in the Cape Chocolate area (Fig. I). He wrote that the delta covers a marine bench located approximately $9 \mathrm{~m}$ (30 ft) above sea-level. Differentiating between a buried marine bench and a buried fluvial bench is not easy. Speden has not described any features of this surface that prove it is of marine rather than fluvial origin. He has apparently called it a marine bench because according to the literature it would appear that a $6-9 \mathrm{~m}(20-30 \mathrm{ft})$ marine bench is widespread around McMurdo Sound. He noted that $6 \mathrm{~m}(20 \mathrm{ft}$ ) and $12 \mathrm{~m}$ (40 $\mathrm{ft}$ ) benches at Cape Bernacchi and a $6+\mathrm{m}(20+\mathrm{ft})$ bench at Taylor Dry Valley have been mentioned by David and Priestley (1914, p. 84, 95). However, the writer in his field work found no evidence for these benches. Moreover, the elevated beaches at Marble Point and elsewhere descend from approximately $18 \mathrm{~m}(6 \mathrm{oft})$ above sea-level to the present coastline 
without any significant break in slope (Fig. 18). The writer, therefore, does not believe that a marine bench approximately $9 \mathrm{~m}$ ( $3 \circ$ li) above sea-level is widespread in the McMurdo Sound area, and does not feel there is any evidence for its existence at Cape Chocolate. Speden $(1960$, p. 209) also mentioned the presence of a $9 \mathrm{~m}$ (30 ft) beach. The writer, howcver, after a careful study found no elevated marine topography at Cape Chocolate with the possible exception of the cliffs cut in the delta and the beach in front of it.

Marine clifflets cut in glacio-fluvial deposits, till and ice are found at Davis Bay (Spcden, 1960, p. 212, 214), al "Broad Delta Bay", on the south side of "Broad Delta Bay" and northwest of the eastern end of the Kukri Hills, between Blue Glacier and Davis Bay, and elsewhere. The bases of these cliffs are found at approximatcly storm-lide level. 'T'he cliffs are too small to have required for their formation any significant still-stand of sca-level at its present position.

The fact that elevaled beaches $20 \mathrm{~m}$ (66 ft) above sea-level occur at Marble Point, whereas only $13 \mathrm{~km}$ ( 8 miles) to the south-west in "Broad Delta Bay" no elevatcd beaches are found, requires explanation. If is certain that beaches have not been formed in this part of "Broad Delta Bay" only to have been buried later by alluvium, talus or solifluction deposits. Moreover, the coastal topography is not everywhere so steep that beaches could not form. Nor can poor exposure, short fetch or shallow offshore profile explain their absence. IL seems likely that the coastal areas from "Broad Delta Bay" to Cape Chocolate were covercd until very recently with the expanded Koettlit:, Bluc and Ferrar Glacicrs. The deglaciation of the area has taken place so recently, and the mass of ice removed during it has been so small, that no significant uplift has taken place, and elevated beachcs, therefore, do not occur. Morcover, the presence of perennial fast ice at the head of "Broad Delta Bay" following deglaciation would also have helped to prevent the formation of elevated beaches (Nichols, Ig63[a]).

\section{Eolian Drposits}

A small eolian dcposit extends fairly continuously for more than $0.8 \mathrm{~km}(0.5 \mathrm{milc}$ ) from the south side of Marble Point nearly to the mouth of the "South River" (Fig. 16). The deposit is found both above and below the marine limit. It is a thin veneer, in most places only I $m$ thick. 'I the good sorting, the absence of large fragments on and in it, the presence of sand shadows on the lee side of obstacles and of sand drifts on their windward side, and its presence in places where only wind could have carried it, prove its eolian origin.

The deposit is found on both gentle and steep slopes and in hollows on both the windward and lecward sides of outcrops. Small climbing dunes are found in the southern part of the area. Here, their development is lavorcd by winds from the south and by a steep slope that trends north-east to south-west and follows the shoreline. Little melt-water drainage crosses these deposits. Miniature frost cracks and frost-crack polygons approximately $3 \mathrm{~m}$ (ioft) in diameter were noted. Eolian deposits are probably formed in this area in carly winter, when the snow cover is not extensive but when the winds are strong.

'I'he fact that this deposit is found only near the strand line strongly suggests that both the modern and the clevated beaches nearby are sources for it. Several hundred yards south of the eolian deposit, the modern and elevated beaches make a broad cxpanse of sand and gravel. "The "South River" Hows over these deposits, continually re-working them and adding to them, so that additional material is constantly being made available for the wind. 'The eolian deposit, in part at least, was derived from this area. This is proved by the following: ( $x$ ) the strong winds come from the south, as indicated by the presence of sand shadows on the north side of obstacles, and this area is south of the eolian deposit; (2) the colian deposit thins to disappearance to the north; and ( 3 ) this area is the best source for eolian deposits. Disintegrating marble and other rapidly weathering rocks provide an additional source. As might be expected, ventifacts are found on the nearby elevated beaches. They are cut on the south side only. 
A still smaller coarse eolian deposit on the south side of Marble Point near its eastern terminus (Fig. 20) buries the beach deposits and, in places, it has been slightly re-worked and thinly veneered with finer-grained fluvial material. A mechanical analysis of this deposit showed that it contains 13 per cent of the granule sizes and, therefore, is much coarser than the average eolian deposit (Twenhofel, 1932, p. 221; Nichols, 1961[b], fig. 3-33). The analysis proves that the winds at times are exceptionally strong.

\section{ACKNOWLedgements}

The Commanding Officer, U.S. Navy Construction Battalion Reconnaissance Unit, provided some of the data. The writer is happy to acknowledge the co-operation and help he received from Commanders Henry C. Stephens and David Feinman, U.S. Navy, and also the assistance and stimulation he received from $\mathrm{Mr}$ Donald G. Ball of Metcalf and Eddy, Engineers, Boston, Massachusetts. Messrs George Denton, Robert Goodspeed, Roger Hart and William Meserve, students at Tufts University; $\mathrm{Mr}$ Robert Rutford, University of Minnesota; Mr Parker E. Calkin of Ohio State University; and Professor Harold W. Borns, Jr., University of Maine, were able field assistants.

\section{MS. received 17 November 1967}

\section{REFERENCES}

Barghoorn, E. S., and Nichols, R. L, 1961. Sulfate-reducing bacteria and pyritic sediments in Antarctica. Science. Vol. 134. No. 3473, p. 190.

David, T. W. E., and Priestley, R. E. 1909. Geological observations in Antarctica by the British Antarctic Expedition, 1907-1909. (In Shackleton. E. H. The heart of the Antarctic: being the story of the British Antarctic Expedition, 1907-1909. London, William Heinemann, Vol. 2, p. 268-314.)

David, T. W. E., and Priestley, R. E. 1914. Glaciology. physiography. stratigraphy. and tectonic geology of south Victoria Land. London, William Heinemann. (Reports on the Scientific Investigations, British Antarctic Expedition. 1907-1909. Geology, Vol, 1.)

Debenham. F. 1920. A new mode of transportation by ice: the raised marine muds of south Victoria Land (Antarctica). Quarterly fournal of the Geological Society of London. Vol. 75. Pt. 2, p. 51-76.

Jolınson, Douglas. 1925. The New England-Acadian shoreline. New York, John Wiley and Sons, Inc.

Nichols. R. L. [1953.] Geomorphology of Marguerite Bay, Palmer Peninsula, Antaretica. Washington. D.C.. Office of Naval Research. (Ronne Antarctic Research Expedition. Technical Report No. 12.)

Nichols, R. L. 1960. (Geomorphology of Marguerite Bay area. Palmer Peninsula. Antarctica. Bulletin of the Geological Society of America, Vol. 71, No. 10, p. 1421-50.

Nichols, R. L. $1961[\mathrm{a}]$. Characteristics of beaches formed in polar climates. American Journal of Science, Vol. 259. No. 9. p. $694-708$.

Nichols, R. L. 196r [b]. Characteristics of beaches formed in polar climates. IGY Glaciological Report Series (New York. IGY World Data Center A. Glaciology, American Geographical Society), No. 4, p. $103-21$.

Nichols, R. L. t96r[c]. Multiple glaciation in the Wright Valley. McMurdo Sound, Antarctica. Abstracts of symposium papers, tenth Pacific Science Congress of the Pacific Science Association, Honolulu, 1961, p. 317.

Nichols, R. L. 1963[a]. Geomorphology of the McMurdo Sound coast. south Victoria Land, Antarctica. Geological Society of America. Stecial Paters. No. 73. p. 211.

Nichols. R. L. $1963 \mid \mathrm{b}]$. Miniature nivation cirques near Marble Point, McMurdo Sound. Antarctica. Journal of Glaciology, Vol. 4, No. 34, p. 477-79.

Nichols. R. L.. 1964. Snowdrift-ice slabs and historic Antarctic climatic warming. Fournal of Glaciology. Vol. 5 . No. 39, p. $345-51$.

Nichols. R. L. 1965 . Antarctic interglacial features. Jounal of Glaciology, Vol. 5. No. 40, p. $433-49$.

Nichols, R. L. 1966. Geomorphology of Antarctica. (In Tedrow. J. C. F. ed. Antarctic soils and soil forming processes. Washington, D.C., American Geophysical Union, p. 1-46. (Antarctic Research Series, Vol. 8.))

Olson, E. A., and Broecker, W. S. 1961. Lamont natural radiocarbon measurements. VII. Radiocarbon. Vol, 3. p. $14 \mathrm{t}-75$.

Péwé, 'T. L. 196o. Multiple glaciation in the McMurdo Sound region, Antarctica - a progress report. Journal of Geology, Vol. 68 , No. 5. p. $49^{8-514}$.

Priestley, R. E. 1922. Geological climates of the Antarctic. (In Wright, C. S., and Priestley, R. E. Glaciology. London, Harrison and Sons, Ltd., p. 418-47. (British (Terra Nova) Antarctic Expedition, 1910-1913.))

Priestley. R. E. 1923. Physiography (Roberison Bay and Terra Nova Bay regions). London. Harrison and Sons, L.td. (British (Terra Nova) Antarctic Expedition, 1910-1913.)

Priestley, R. E., and David, T. W. E. 1912. Geological notes of the British Antarctic Expedition, $1907-1909$. Compte Rendu du XIe Congrès Géologique International, Stockholm, 1910, p. 767-811. 
Shepard, F. P. 1937. Revised classification of marine shorelines. Journal of Geology, Vol. 45, No. 6, p. 602-24.

Shepard, F. P. 1964 . Sea level changes in the past 6000 ycars: possible archeological significance. Science, Vol. 143 , No. 3606 , p. $574-76$.

Soot-Ryen, T. 1951. Antarctic pelecypods. Scientific Results of the Norwegian Antarctic Expeditions, 1927-1928

et seq.. No. 32 .
Speden, I. G. 1960. Post-glacial terraces near Cape Chocolate, McMurdo Sound, Antarctica. New Zealand Founal of Geology and Geophysics, Vol. 3, No. 2, p. 203-1 7.

Taylor. T. G. 1922. The physiography of the McMurdo Sound and Granite Harbour region. London, Harrison and Sons, Ltd. (British (Terra Nova) Antarctic Expedition, 1910-1913.)

Twenhofel, W. H. 1932. Treatise on sedimentation. Baltimore, Williams and Wilkins Co.

Wright, C. S., and Priestley, R. E. 1922. Glaciology. London, Harrison and Sons, Ltd. (British (Terra Nova) Antarctic Expedition, 1910-1913.) 